\title{
Gene expression profiling in acute allograft rejection: challenging the immunologic constant of rejection hypothesis
}

\author{
Tara L Spivey ${ }^{1,2,3}$, Lorenzo Uccellini ${ }^{1,4}$, Maria Libera Ascierto ${ }^{1,5,6}$, Gabriele Zoppoli, ${ }^{5,7}$, Valeria De Giorgi ${ }^{1}$, \\ Lucia Gemma Delogu ${ }^{8}$, Alyson M Engle ${ }^{1}$, Jaime M Thomas ${ }^{1}$, Ena Wang ${ }^{1}$, Francesco M Marincola ${ }^{1 *}$ and \\ Davide Bedognetti ${ }^{1,5,9^{*}}$
}

\begin{abstract}
In humans, the role and relationship between molecular pathways that lead to tissue destruction during acute allograft rejection are not fully understood. Based on studies conducted in humans, we recently hypothesized that different immune-mediated tissue destruction processes (i.e. cancer, infection, autoimmunity) share common convergent final mechanisms. We called this phenomenon the "Immunologic Constant of Rejection (ICR)." The elements of the ICR include molecular pathways that are consistently described through different immunemediated tissue destruction processes and demonstrate the activation of interferon-stimulated genes (ISGs), the recruitment of cytotoxic immune cells (primarily through CXCR3/CCR5 ligand pathways), and the activation of immune effector function genes (IEF genes; granzymes A/B, perforin, etc.).

Here, we challenge the ICR hypothesis by using a meta-analytical approach and systematically reviewing microarray studies evaluating gene expression on tissue biopsies during acute allograft rejection. We found the pillars of the ICR consistently present among the studies reviewed, despite implicit heterogeneity.

Additionally, we provide a descriptive mechanistic overview of acute allograft rejection by describing those molecular pathways most frequently encountered and thereby thought to be most significant. The biological role of the following molecular pathways is described: IFN- $\gamma$, CXCR3/CCR5 ligand, IEF genes, TNF- $\alpha$, IL-10, IRF-1/STAT-1, and complement pathways. The role of NK cell, B cell and T-regulatory cell signatures are also addressed.
\end{abstract}

\section{Introduction}

Defining the interplay between molecular pathways within highly complex biological systems, such as those between immune cell networks and target tissues, is certainly a daunting task. The advent of high-throughput gene expression technology has served as an extremely useful tool to enable investigators to characterize biological events taking place within humans, reducing the inherent bias often generated by testing specific but restricted hypotheses derived from animal models. Previously, we applied this approach to profiling tumor lesions in humans, before and after immunotherapy, to

\footnotetext{
* Correspondence: FMarincola@cc.nih.gov; Davide.Bedognetti@nih.gov 'Infectious Disease and Immunogenetics Section (IDIS), Department of Transfusion Medicine, Clinical Center and trans-NIH Center for Human Immunology (CHI), National Institutes of Health, Bethesda, Maryland, 20892, USA

Full list of author information is available at the end of the article
}

identify molecular pathways activated during immunemediated tumor rejection. These pathways illustrate a process characterized by the coordinated activation of interferon stimulated genes (ISGs), the recruitment of cytotoxic cells through the massive production of specific chemokine ligands, and the activation of immune effector function (IEF) genes (genes expressed by NK cells and CD8 T cells upon activation) [1-4]. Similar pathways have been described among other immunemediated tissue destruction processes such as those occurring during autoimmunity, graft versus host disease (GVHD), infection clearance, acute cardiovascular events, chronic obstructive pulmonary disease, and placental villitis [5-10]. These observations suggest that these distinct tissue destruction processes share common final immune-mediated molecular mechanisms. We termed this phenomenon as the "Immunologic

\section{Biomed Central}


Constant of Rejection (ICR) [3]." The molecular constants shared among these different tissue destruction processes include the coordinated activation of the following pathways: I) STAT-1/IRF-1/T-bet/IFN- $\gamma /$ IL-15 pathway; II) CXCR3 ligand chemokine pathway (CXCL9, -10, -11) III) CCR5 ligand chemokine pathway (CCL3, -4, -5) and IV) TIA-1 pathway/granzyme A/B/ granulysin/perforin pathway $[3,4]$.

Over the past decade gene expression microarrays have been employed to study allograft rejection in humans. The intrinsic heterogeneity among different investigators in terms of patient selection, microarray platforms, gene coverage, statistical analysis, sample collection and study design makes cross-comparison between different studies very challenging. Furthermore, since microarray profiling is a relatively new technology, it has continued to evolve in sophistication and has only recently become standardized $[11,12]$. For this reason we believe that despite the non-uniformity among studies, genes that are consistently reported across different studies and in different organs command attention. In this review we challenge the concept of the ICR by examining multiple studies to evaluate the presence of the "constants of rejection." We tested the ICR hypothesis by describing the most frequently reported immune pathways activated during acute allograft rejection in humans as reported by publications using microarray technologies. Biological explanations for relevant pathways are provided based on pertinent literature.

\section{Data Extraction Criteria}

In this review we focused on high-throughput gene expression profiling studies which sought to characterize the molecular features of acute allograft rejection. Accordingly, we searched various combinations of the following $\mathrm{MeSH}$ terms/keywords in PubMed: "gene expression, " "acute, " "allograft, " "rejection, " and "microarray." Searches were performed independently by two investigators. Gene Expression Omnibus (GEO) and reference lists of original articles and review articles also served as additional search methods. Microarray studies providing original data and performed on human tissue biopsies during established acute allograft rejection were selected and evaluated [13-46]). Studies analyzing gene expression profiles of peripheral blood mononuclear cells and urine sediments during acute rejection will not be considered here, despite their potential utility as noninvasive diagnostic/predictive tools [47-51].

The compiled list of key genes in this review came from those reported as upregulated in the original publications, most of which were predominantly immunerelated and are reported in Table 1. In total, 15 unique datasets met the search criteria, and comprise Tables 1 and 2. Of these datasets, four comparative analyses were among those selected for inclusion. Of note, all of the studies contained original data from de novo investigation.

The Ingenuity Systems Pathway Analysis (IPA) http:// www.ingenuity.com and MetaCore http://www.genego. com were used to illustrate the relationships among the compiled list of key genes. Additional detail regarding the data extraction is provided in Additional File 1.

\section{Overview of microarray studies}

Considering the heterogeneity among the selected studies in terms of platform used, purpose, design, and interpretation (see also Table 2), a quantitative approach was not feasible, making this review qualitative in nature. The diversity of the clinical setting (pediatric or adult patients; heart, lung, liver or kidney transplants) also added complexity to this analysis. The purposes of the original studies included here ranged between class discovery, class comparison, and/or class prediction. Different methods (summarized in Table 2) were used by different investigators to provide a list of genes modulated during acute allograft rejection. Not surprisingly, little overlap exists among studies with respect to specific 'genes' described as upregulated during acute rejection, yet, we found a striking consistency in terms of pathway overrepresentation suggesting that each individual study identified different pieces of the same puzzle.

It should be noted that these studies lacked the use of micro/macro-dissection which prohibited identification of the cellular source of the transcripts differentially expressed during acute rejection. It is logical to think that analysis of RNA from the whole tissue samples could influence gene expression patterns. With this in mind, Sarwal et al. [22], investigated if the molecular changes observed during allograft rejection could have been related to the differential sampling of cortical and medullary kidney sections. For this analysis the authors excluded the genes whose expression was shown to be correlated with the depth of biopsy in a previous investigation. The introduction of this filter did not significantly change the results. In another study involving kidney recipients, Rodder et al. [29] performed qRTPCR on isolated glomeruli, and on proximal and distal tubules. Although qRT-PCR of targets genes (metzincins and related genes) revealed some differences between glomeruli and tubules, it confirmed, overall, the differences between acute rejection and normal samples detected by microarray analysis.

\section{The Immunologic Constant of Rejection pathways in acute allograft rejection}

After reviewing the literature, we found that pathways involved in the ICR hypothesis are frequently activated during acute allograft rejection across studies conducted 
Table 1 Key genes associated with acute allograft rejection according to human microarray studies

\begin{tabular}{|c|c|c|c|c|c|c|c|c|c|}
\hline \multicolumn{10}{|c|}{$\begin{array}{l}\text { Author: Tannapfel et al. } 2001[14] \\
\text { Organ: Liver }\end{array}$} \\
\hline IL3 & MMP9 & TGF-B1-3 & TIMP1 & TNF & $\begin{array}{l}\text { CLUSTERIN } \\
\text { (CLU) }\end{array}$ & IL10 & & & \\
\hline \multicolumn{10}{|c|}{$\begin{array}{l}\text { Author: Sreekumar et al. } 2002[15] \\
\text { Organ: Liver }\end{array}$} \\
\hline$\overline{C 1 Q B}$ & C3 & LIPC & GZMB & HSPA1A & IGF1 & IL2 & (IRF9*) & STAT1 & ACADM \\
\hline HLA-I & HLA-II & PCK1 & SELPLG & TGFB1 & TNF & TNFAIP3 & TNFSF10 & $\mathrm{UBB}^{3 \#}$ & UBA1 \\
\hline UBE2N & ADAM17 & GYS2 & CTPS & & & & & & \\
\hline \multicolumn{10}{|c|}{$\begin{array}{l}\text { Inkinen et al. } 2005 \text { [16] } \\
\text { Organ: Liver }\end{array}$} \\
\hline HLA-D & IL2RB & IL2RG & CASP1 & CASP3 & GZMA & GZMB & SELL & ICAM3 & ITGA4 \\
\hline$\overline{\text { SELE }}$ & VCAM1 & IFNG & IL1B & & & & & & \\
\hline \multicolumn{10}{|c|}{$\begin{array}{l}\text { Asaoka et al. } 2009 \text { [28] } \\
\text { Organ: Liver }\end{array}$} \\
\hline AKAP11 & ALOX15 & CASP8 & CFLAR & FFAR3 & IFNAR1 & IGFBP3 & IL12RB1 & LTA & POU4F1 \\
\hline PPP1R8 & PPP1R3A & PVRL1 & TNK2 & & & & & & \\
\hline \multicolumn{10}{|c|}{$\begin{array}{c}\text { Author: Gimino et al. } 2003 \text { [17]Lande et al. } 2006 \text { [30](MINNEAPOLIS Dataset) } \\
\text { Organ: Lung }\end{array}$} \\
\hline C4B & CCR7 & CD28 & CD3E & CD84 & CTLA4 & CXCR3 & GZMK & GZMA & IFNG \\
\hline IGKC & ITK & KIR & PRF1 & STAT4 & IL2RA & IL2RB & Zap70 & LCK & \\
\hline \multicolumn{10}{|c|}{$\begin{array}{l}\text { Patil et al. } 2008 \text { (MINNEAPOLIS2 Dataset) [18] } \\
\text { Organ: Lung }\end{array}$} \\
\hline IFITM1 & CD8A & MARCKS & CCL3 & GZMB & ITM2A & IL32 & IL8 & CCL4 & \\
\hline \multicolumn{10}{|c|}{$\begin{array}{l}\text { Author: Karason et al. } 2006 \text { [19] } \\
\text { Organ: Heart }\end{array}$} \\
\hline $\mathrm{C} 3$ & C4A & CXCL9 & CXCL10 & GBP1 & HLA-C & HLA-F & HLA-J & IGFBP4 & NPPA \\
\hline PSME2 & RARRES3 & STAT1 & & & & & & & \\
\hline \multicolumn{10}{|c|}{$\begin{array}{l}\text { Author: Akalin et al. } 2001 \text { [21] } \\
\text { Organ: Kidney }\end{array}$} \\
\hline $\begin{array}{l}\text { Humig } \\
\text { (CXCL9) }\end{array}$ & C3 & $\begin{array}{l}\text { CD18 } \\
\text { (ITGB2) } \\
\end{array}$ & $\begin{array}{l}\text { ISGF-3 } \\
\text { (STAT1) }\end{array}$ & MCL1 & $\begin{array}{l}\text { MIP-3 } \\
\text { (CCL19) }\end{array}$ & NNMT & $\begin{array}{l}\text { RING4 } \\
\text { (TAP1) }\end{array}$ & TCRB $^{\#}$ & $\begin{array}{l}\text { IL2-SP }^{2 \#} \\
\text { (LCP1) }\end{array}$ \\
\hline \multicolumn{10}{|c|}{$\begin{array}{c}\text { Author: Sarwal et al. } 2003 \text { (STANFORD Dataset) [22] } \\
\text { Organ: Kidney }\end{array}$} \\
\hline HLA-A & HLA-B & HLA-C & HLA-E & HLA-DR & HLA-DQ & HLA-DMA & HLA-DRB4 & TGFBR2 & TGFR1 \\
\hline TCR & DARC & C4B & CXCL9 & $\begin{array}{l}\text { SCYA3 } \\
\text { (CCL3) }\end{array}$ & $\begin{array}{l}\text { SCYA5 } \\
\text { (CCL5) }\end{array}$ & CCR5 & $\begin{array}{l}\text { SCYA2 } \\
\text { (CCL2) }\end{array}$ & CD20 & PERFORIN \\
\hline CD53 & NFKB1 & $\begin{array}{l}\text { NK4 } \\
\text { (IL32) }\end{array}$ & CX3CR1 & GZMA & STK17B & IL6R & IL2RB & IL15RA & IL16 \\
\hline STAT1 & CASP10 & IFNGR1 & IGHG3 & IGKC & IGL & IGHM & LENG4 & CD59 & VCAM1 \\
\hline$\overline{\text { CXCL9 }}$ & CXCL10 & CCR5 & & & & & & & \\
\hline \multicolumn{10}{|c|}{$\begin{array}{c}\text { Author: Flechner et al. } 2004 \text { (CLEVELAND Dataset) [23] } \\
\text { Organ: Kidney }\end{array}$} \\
\hline$\overline{C 1 Q B}$ & CCL5 & CD14 & CD163 & TRB@ & CD16 & $\mathrm{CD} 2$ & CD27 & CD3D & CD48 \\
\hline CD53 & $\begin{array}{l}\text { CD64 } \\
\text { (FCGR1A) }\end{array}$ & CD8 & CDW52 & CXCR4 & GZMA & HLA-F & IFI30 & IL10RA & IL10RB \\
\hline IL4R & ISG20 & $\begin{array}{l}\text { PKR } \\
\text { (PRKRA) }\end{array}$ & $\begin{array}{l}\text { RAGE4 } \\
\text { (RAGE) }\end{array}$ & TNFRSF1 & & & & & \\
\hline \multicolumn{10}{|c|}{$\begin{array}{c}\text { Reeve et al. } 2009 \text { (EDMONTON Dataset) [24] } \\
\text { Organ: Kidney }\end{array}$} \\
\hline APOBEC3G & CCL4 & CCL5 & CD8A & CRTAM & CXCL9 & CXCL10 & CXCL11 & FAM26F & GBP1 \\
\hline$\overline{\text { GBP2 }}$ & GBP4 & GBP5 & GZMA & GZMB & INDO & LCP2 & LILRB1 & NLRC5 & PSMB9 \\
\hline
\end{tabular}


Table 1 Key genes associated with acute allograft rejection according to human microarray studies (Continued)

\begin{tabular}{|c|c|c|c|c|c|c|c|c|c|}
\hline \multicolumn{10}{|c|}{$\begin{array}{l}\text { Author: Morgun et al. } 2006 \text { (SAN PAULO Dataset) [25] } \\
\text { Organ: Heart + Lung + Kidney } \\
\text { (SAN PAULO+ MINNEAPOLIS+STANFORD+CLEVELAND Datasets) }\end{array}$} \\
\hline $\mathrm{ABCA7}$ & CD14 & DAP10 & HLA-A & HSD17B7 & ISG20 & LEF1 & NT5C2 & $\mathrm{RU} 2$ & TRAF2 \\
\hline ADAM15 & CD2 & F2R & HLA-B & HSPC043 & ISGF3G (IRF9) & LIAS & PAK4 & SELPLG & TRB@ \\
\hline ADAM8 & CD3Z & FCER1G & HLA-DMA & HSPC129 & ITGB2 & LILRB4 & PCDHGA8 & SLC14A2 & UBD \\
\hline B2M & CD53 & FKBP14 & HLA-DMB & IFI30 & KCNJ5 & LOC90586 & PSCD4 & SMG1 & UBE1L \\
\hline$\overline{B A X}$ & CD7 & FLJ10244 & HLA-DQB1 & IGHG3 & KCNK6 & LOC92033 & PSMB9 & SORL1 & UBE2B \\
\hline BTN3A3 & CD74 & FL11106 & HLA-DRA & IGKC & KIAA0924 & LTB & PSME1 & STAT1 & UBE2L6 \\
\hline C1QA & CG012 & FLJ11151 & HLA-DRB1 & IGLC2 & KIAA1030 & LTB4R & RAB7L1 & SULT1A3 & UCP2 \\
\hline $\mathrm{C4A}$ & CHD3 & FLJ11467 & HLA-DRB3 & IGLC6 & KIAA1170 & MAFF & RAC2 & TAP1 & WSX1 (IL27RA) \\
\hline CASP4 & CORO1A & $\mathrm{FY}$ & HLA-DRB5 & IGLJ3 & KIAA1257 & MSH3 & RARRES3 & TAPBP & ZAP70 \\
\hline CCL18 & CTSS & GMFG & HLA-E & IL2RB & KIAA1348 & NKG7 & RASGRP2 & $\begin{array}{l}\text { TCBRV } \\
\text { (IL23A) } \\
\end{array}$ & ZNRD1 \\
\hline$\overline{\mathrm{CCL} 5}$ & CX3CL1 & GZMK & HLA-F & IRF3 & LAT & $\mathrm{NM} 23-\mathrm{H} 6$ & RBL1 & TNFAIP3 & TNFSF13B \\
\hline$\overline{\text { CXCL9 }}$ & D21S2056E & $\mathrm{HA}-1$ & HLA-G & IRF5 & LCK & NPHP1 & RIMS1 & & \\
\hline \multicolumn{10}{|c|}{$\begin{array}{l}\text { Reference: Saint-Mezard et al. } 2008 \text { (PARIS Dataset) [26] } \\
\text { Organ: Kidney } \\
\text { RIS+STANFORD+CLEVELAND+NON HUMAN PRIMATES Datasets) }\end{array}$} \\
\hline$\overline{A R H G D I B}$ & ARPC2 & CASP1 & CASP4 & CCL5 & CD163 & CD44 & CD48 & CD52 & CD53 \\
\hline CD8A & CSPG2 & CXCL10 & CXCL9 & FCER1G & FER1L3 & GBP1 & GBP2 & GMFG & GZMA \\
\hline$\overline{\mathrm{HCK}}$ & HCLS1 & HLA-B & HLA-C & HLA-DMA & HLA-DMB & $\begin{array}{l}\text { HLA- } \\
\text { DPA1 }\end{array}$ & $\begin{array}{l}\text { HLA- } \\
\text { DQB1 }\end{array}$ & HLA-DQB2 & HLA-DRA \\
\hline $\begin{array}{l}\text { HLA- } \\
\text { DRB3 }\end{array}$ & HLA-E & HLA-F & HLA-G & IFI30 & IFITM1 & IGHM & IL10RA & ISG20 & ITGB2 \\
\hline LAPTM5 & LCK & LCP1 & LCP2 & LTF & LYZ & MMP7 & $\mathrm{NMI}$ & PLEK & PLSCR1 \\
\hline$\overline{P R G 1}$ & PRKCB1 & PSMB10 & PSMB8 & PSMB9 & RAC2 & RUNX3 & SERPING1 & SLA & STAT1 \\
\hline TAP1 & TCIRG1 & TIMP1 & TNC & TNFRSF7 & UBD & UBE2L6 & WARS & WFDC2 & $\begin{array}{l}\text { T3JAM } \\
\text { (TRAF3IP3) }\end{array}$ \\
\hline
\end{tabular}

\begin{tabular}{|c|c|c|c|c|c|c|c|c|c|}
\hline \multicolumn{10}{|c|}{$\begin{array}{c}\text { Rodder et al. } 2010 \text { (TENON/INSELSPITAL Dataset) [29] } \\
\text { Organ: Kidney } \\
\text { Meta-analysis focused on metzincins and related genes } \\
\text { ON/INSELSPITAL+EDMONTON+STANFORD+ CLEVELAND Datasets) }\end{array}$} \\
\hline TIMP1 & MMP7 & ADAMTS18 & ADAMTS6 & ADAMTS17 & ADAMTS8 & ADAMTSL4 & ADAM18 & TLL2 & ADAM17 \\
\hline PLG & LAMA4 & EMILIN2 & & & & & & & \\
\hline \multicolumn{10}{|c|}{$\begin{array}{c}\text { Chen et al. } 2010 \text { (STANFORD2 dataset) [27] } \\
\text { Organs: Kidney, Heart } \\
\text { (STANFORD2+CLEVELAND+SAN PAULO Datasets) }\end{array}$} \\
\hline CXCL9 & CXCL11 & CXCR4 & STAT1 & CCL4 & C6orf32 & MARCKS & IGSF6 & $\mathrm{CD} 2$ & TRPM1 \\
\hline IL10RA & RARRES3 & NR4A2 & PTPRC & LEF1 & TAP1 & CTSS & ISG20 & CCL8 & BASP1 \\
\hline SLC2A3 & LCP2 & HLA-DMA & BIRC5 & HLA-DMB & CASP4 & SELL & $\mathrm{HLA}-\mathrm{F}$ & CD44 & HLA-DQB1 \\
\hline PIK3CD & PECAM1 & MDK & MELK & CDKN3 & CPD & $\mathrm{SH} 2 \mathrm{D} 2 \mathrm{~A}$ & CCNB2 & HLA-DRA & B2M \\
\hline DIAPH1 & USP34 & SCAND2 & RUNX1 & S100A4 & & & & & \\
\hline
\end{tabular}

Genes underlining highly redundant themes among studies are in bold.

This table reports upregulated genes associated with acute allograft rejection detected by microarrays technology analyzing human graft samples (bronchoalveolar lavage for lung samples, tissue biopsies for the other samples). Additional detail regarding the data extraction is provided in Additional file 1. *Synonymous gene symbols, according to NCBI Gene, are provided in brackets.

${ }^{\#}$ The original name reported in the publication was: TCR Active $\beta$-chain related gene (M12886: unmapped). ${ }^{2 \#}$ The original name reported in the publication was: IL-2-stimulated phosphoprotein. ${ }^{3 \#}$ The original name reported in the publication was: ubiquitin. 
Table 2 Characteristics of microarray studies evaluating gene expression profile in acute allograft rejection biopsies in humans.

\begin{tabular}{|c|c|c|}
\hline $\begin{array}{c}\text { Author } \\
\text { (dataset) } * \\
\text { Year } \\
\text { Organ } \\
\text { (samples) }\end{array}$ & Array $^{+}$ & Aim/Design $^{\ddagger}$ \\
\hline $\begin{array}{l}\text { Tannapfel et al. } \\
{[14]} \\
2001 \\
\text { Liver (biopsies) }\end{array}$ & $\begin{array}{l}\text { Atlas human cDNA } \\
\sim 600 \text { genes }\end{array}$ & $\begin{array}{l}\text { Aim. To investigate the expression of multiple inflammatory and apoptosis related genes in } \\
\text { acute allograft rejection. } \\
\text { Design. (Adults) } 62 \text { patients, } 97 \text { biopsies: acute allograft rejection }(n=32) \text {, HCV reinfection ( } n \\
=18) \text {, CMV infection }(n=5) \text {, acute rejection and HCV infection }(n=3) \text {, stable graft function ( } n \\
=30 \text { ) and after treatment of acute rejection }(n=9) \text {. } \\
\text { Statistics. Not available. }\end{array}$ \\
\hline
\end{tabular}

Sreekumar et al. Affymetrix HU 6800

[15] $\sim 6,400$ genes

2002

Liver (biopsies)

\begin{tabular}{ll}
\hline Inkinen et al. & Turku Centre of Biotechnology \\
{$[16]$} & human immunochip \\
2005 & $\sim 4,600$ genes \\
Liver (biopsies) &
\end{tabular}

Liver (biopsies)

\begin{tabular}{ll}
\hline Asaoka et al. & AceGene Human chip \\
[28] & $\sim 30,000$ genes
\end{tabular}

2009

Liver (biopsies)
Aim. To study intragraft gene expression patterns in acute cellular rejection and during recurrence of HCV in HCV infected recipients.

Methods. (Adults) 8 patients and biopsies: HCV infection and acute cellular rejection $(n=4)$, $\mathrm{HCV}$ infection without acute cellular rejection $(n=4)$. Statistics. T-tests and fold change threshold.

Aim. To determine and compare gene signature of CMV infection and acute rejection. Methods. (Adults) 7 patients and biopsies: CMV infection $(n=4)$, patients with acute rejection $(n=3)$.

Gene expression of CMV and acute rejection samples were compared to that of liver graft after reperfusion.

Statistics. Not available

Aim. To identify genes characteristic of acute cellular rejection in patients with recurrent HCV infections.

Methods. (Adults) $21 \mathrm{HCV}$ positive patients, 22 biopsies: acute cellular rejection $(\mathrm{n}=9)$, without acute cellular rejection $(n=13)$. The expression of some transcripts (CASP8 and BMP2) was validated through qRT-PCR in this data set and also in a validation set: 32 biopsies from $25 \mathrm{HCV}$ positive patients.

Statistics. Class discovery: unsupervised clustering analysis. Class comparison: Mann Whitney U test, supervised cluster analysis. Biological explanation: networks were built by Ingenuity Pathway Analysis (IPA).

\begin{tabular}{|c|c|c|}
\hline $\begin{array}{l}\text { Gimino et al. } \\
{[17]} \\
\text { (Minneapolis } \\
\text { Dataset) } \\
2003\end{array}$ & $\begin{array}{l}\text { Affymetrix Human Genome } \\
\text { U133A } \\
\sim 18,000 \text { genes }\end{array}$ & $\begin{array}{l}\text { Aim. To determine markers of acute rejection in lung recipients. } \\
\text { Methods. (Adults) } 26 \text { patients, } 34 \text { samples: acute rejection }(n=27) \text {, without diagnosis of } \\
\text { rejection }(n=7) \text {. } \\
\text { Statistics. Class comparison: significance analysis of microarray. Class description: supervised } \\
\text { clustering analysis. }\end{array}$ \\
\hline
\end{tabular}

Lung $(B A L)$

Patil et al. [18] Affymetrix Human Genome (Minneapolis2 U133A

Dataset) $\quad \sim 18,000$ genes

2008

Lung (BAL)

\begin{tabular}{ll}
\hline Karason et al. & Affymetrix Human Genome \\
{$[19]$} & U133A \\
2006 & $\sim 18,000$ genes \\
Heart (biopsies) &
\end{tabular}

Heart (biopsies) (1) 
Table 2 Characteristics of microarray studies evaluating gene expression profile in acute allograft rejection biopsies in humans. (Continued)

\begin{tabular}{ll}
\hline Sarwal et al. & Lymphochip \\
[22] & $>12,000$ genes \\
(Stanford & \\
Dataset) & \\
2003 & \\
Kidney & \\
(biopsies) &
\end{tabular}

Aim. To investigate the possibility that variations in gene-expression patterns in allograft-biopsy samples from patients with acute rejection and related disorders could identify molecularly distinct subtypes of acute rejection to possibly explain differences in clinical behavior.

Design. (Pediatric patients) 50 patients. 67 biopsies: biopsies during acute or chronic allograft dysfunctions $(n=52)$ and at the time of the engraftment or when graft function was stable ( $n$ $=15$ ). The possibility of different sampling of the medullary and the cortical regions was also addressed.

Statistics. Class discovery: unsupervised clustering analysis. Class comparison: significance analysis of microarray. Survival analysis: Kaplan-Meyer/Cox log-rank method. Biological explanation: enrichment of specific functional groups through evaluation of hypergeometric distribution. The exclusion of data from genes whose expression was correlated with the depth of biopsy did not change the cluster analysis.

\begin{tabular}{ll}
\hline Flechner et al. & Affymetrix \\
[23] & HG-U95Av2 \\
(Cleveland & $\sim 10,000$ genes \\
Dataset) & \\
2004 & \\
Kidney & \\
(biopsies and & \\
PBLs) &
\end{tabular}

Aim. To determine gene expression profiling in transplant patients including: normal donor kidneys, well functioning transplants without rejection, kidneys undergoing acute rejection, and transplants with renal dysfunction without rejection.

Design. (Adults) 23 graft recipients and 9 donors. Acute rejection biopsies $(n=7)$, renal dysfunction without rejection on biopsies $(n=6)$, biopsies carried out more than one year post transplant in patient with good transplant function and normal histology $(n=10)$, biopsies from living donor controls $(n=9)$. PBLs were also collected and profiled. Expression of some transcript was also assessed through qRT-PCR.

Statistics. Class discovery: unsupervised clustering analysis. Class comparison: significance analysis of microarray filtered with limit fold model and MAS 5.0 present/absent calls. Classprediction: leave-one-out method. Biological explanation: analysis of functional classes of the differentially expressed genes.

Reeve et al. [24] Affymetrix Human Genome U133 Aim. To define a classifier to distinguish rejection vs non rejection using predictive analysis for (Edmonton Plus 2.0 Dataset) > 38, 000 genes

2009

Kidney

(biopsies) microarrays

Design. (Adults) 143 patients, 186 biopsies: acute rejection samples (acute cellular rejection, antibody mediated rejection or mixed) $(n=51)$, non-rejection samples $(n=135)$.

Statistics. Class comparisons: Bayesian t-test and false discovery rate. Class prediction: prediction analysis of microarrays. Biological explanation: analysis of functional classes of the differentially expressed genes according to KEGG pathways and to authors' defined pathogenesis-based transcripts.

\begin{tabular}{ll}
\hline Morgun et al. & Qiagen/Operon Array \\
[25] & $\sim 14,000$ genes \\
(San Paulo & \\
Dataset) & \\
2006 & \\
Heart (biopsies) &
\end{tabular}

Aim. To analyze gene expression differences between rejection, non rejection and Trypanosoma cruzi infection.

Design. (Adults) 40 patients, 76 biopsies (rejection, no rejection and Trypanosoma cruzi infection recurrence). Expression of some transcripts was also assessed through qRT-PCR. Statistics. Class comparison: random variance t-test filtered with univariate/multivariate tests for false discovery rates; supervised clustering analysis. Class prediction: 6 different multivariate models models (compound covariate predictor, diagonal linear discriminant analysis, 1- and 3nearest neighbor predictor, nearest centroid predictor, support vector machine) and leave-oneout cross validation. The authors validated the predictor-set in independent datasets of biopsies (collected on different continents and analyzed with different chip batches). The authors also tested the predictor set by analyzing the data from data from Cleveland (Kidney) Stanford (Kidney) and Minneapolis (Lung) datasets.

Biological explanation: Database Annotation, Visualization and Integrated Discovery (DAVID)/ Gene Ontology and KEGG Pathways.

Saint-Mezard et Affymetrix Human Genome U133 Aim. To identify a robust and reliable molecular signature for acute rejection in humans. al. [26] $\quad$ Plus 2.0

(Paris Dataset) > 38, 000 genes

2008

Design. (Adults) 45 patients, 47 biopsies: acute rejection $(n=8)$, acute rejection and chronic allograft nephropathy $(n=8)$, borderline $(n=3)$, non rejection $(n=7)$, and chronic allograft nephropathy $(n=22)$. Normal kidney tissue was obtained from histopathologically unaffected areas of the cortex of native nephrectomies performed for renal carcinoma was used as control.

Statistics. Genes differentially expressed (Paris Dataset) were intersected with those from with 2 public human datasets: 1) Stanford Dataset and 2) Cleveland Dataset and with one Non Human Primate (NHP) model of acute renal allograft. However, the authors used biopsy microarray data from Edmonton Dataset as in independent confirmation set. Score from the identified classifier was correlated with the histopathological Banff score. Expression of some transcripts was also assessed through qRT-PCR.

Class comparison: ANOVA with or without false discovery rate and additional cutoff based on twofold change. Class discovery: Principal component analysis, supervised clustering analysis (using the genes differentially expressed in all four datasets); Class prediction: leave-one-out cross-validation and 10-fold cross-validation. Biological explanation: Gene regulatory networks were generated using MetaCore. 
Table 2 Characteristics of microarray studies evaluating gene expression profile in acute allograft rejection biopsies in humans. (Continued)

\begin{tabular}{|c|c|c|}
\hline $\begin{array}{l}\text { Rodder et al. } \\
\text { [29] } \\
\text { (Tenon/ } \\
\text { Inelspital } \\
\text { Dataset) } \\
2011 \\
\text { Kidney } \\
\text { (biopsies) }\end{array}$ & $\begin{array}{l}\text { Affymetrix Human Genome U133 } \\
\text { Plus } 2.0 \\
>38,000 \text { genes }\end{array}$ & $\begin{array}{l}\text { Aim. To identify the expression of metzincins and related genes in allograft rejection biopsies. } \\
\text { Design. (Adults) } 41 \text { biopsies: normal histology }(n=20) \text {, borderline changes }(n=4) \text {, acute } \\
\text { rejection ( } n=10) \text { and acute rejection and interstitial fibrosis/tubular atrophy }(n=7) \text {. Expression } \\
\text { of some transcripts was also assessed through qRT-PCR. } \\
\text { Statistics. Class prediction: ANOVA and shrinking centroids methods were used for variable } \\
\text { selection and a variety of classification methods were tested. Leave-one-out method was } \\
\text { performed as internal cross-validation. Classifier performance was estimated as correct rate after } \\
\text { 1-level cross validation. The model was validated in Edmonton, Cleveland and Stanford } \\
\text { datasets. Gene set scores from biopsies were also determined and correlated with Banff scores. }\end{array}$ \\
\hline $\begin{array}{l}\text { Chen et al. [27] } \\
\text { (Stanford2 } \\
\text { Dataset) } \\
2011 \\
\text { Kidney } \\
\text { (biopsies) }\end{array}$ & $\begin{array}{l}\text { Affymetrix Human Genome U133 } \\
\text { Plus } 2.0 \\
>38,000 \text { genes }\end{array}$ & $\begin{array}{l}\text { Aim. To identify biomarkers across similar conditions through integration of related datasets. } \\
\text { Methods. (Pediatric patients) } 36 \text { patients and biopsies: acute rejection biopsies ( } \mathrm{n}=18) \text {, stable } \\
\text { function biopsies ( } \mathrm{n}=18 \text { ). } \\
\text { Statistics. Class comparison: significance analysis of microarrays and fold change filter. The } \\
\text { upregulated genes during acute rejection were intersected with genes upregulated during } \\
\text { acute rejection in two other datasets (Cleveland and San Paulo). }\end{array}$ \\
\hline
\end{tabular}

Notes

*For the Minneapolis Dataset only the publication by Gimino et al. is described;

${ }^{\dagger}$ Microarray chips details: Atlas human cDNA microarrays 588 gene analyzed; Affymetrix GeneChip HU6800 Array containing > 7, 000 oligonucleotide probe sets representing $\sim 6,400$ human genes (Affymetrix, Santa Clara, CA);

Affymetrix Human Genome U133A Array containing $>$ 22, 000 oligonucleotide probe sets representing $>18,000$ transcripts ( 14, 500 human genes) (Affymetrix Santa Clara, CA); Lymphochip: in-house microarrays containing > 28, 000 cDNA probes representing > 12, 000 genes (Stanford University); Affymetrix GeneChip HG-U95Av2 Array containing 12, 000 oligonucleotide probes representing 10, 000 human genes; Affymetrix Human Genome U133A Array containing > 22, 000 oligonucleotide probe sets representing > 18, 000 transcripts ( 14, 500 human genes) (Affymetrix, Santa Clara, CA); Affymetrix Human Genome U133 Plus 2.0 Array containing $>54,000$ oligonucleotide probe sets representing > 47, 000 transcripts ( 38, 500 human genes) (Affymetrix, Santa Clara, CA); Qiagen/ Operon array: in-house oligonucleotide array platform designed by Qiagen/Operon (Alameda, CA) and printed at NIAID Microarray facility, representing 14, 000 human genes;

${ }^{\text {\#} S t u d y}$ aim/design is referred to gene expression experiments;

Abbreviations: BOS: Bronchiolitis obliterans syndrome; PBLs: Peripheral blood lymphocyte; CMV: cytomegalovirus; HCV: hepatitis C virus; qRT-PCR: quantitative real time polymerase chain reaction;

by different investigators in different organs (see Table 1 ). Figure 1 provides a visualization of the relationships among the key genes described. Here, we attempt to illustrate the hypothetical role of these pathways during acute allograft rejection.

\section{IFN- $\gamma$ pathway}

IFN- $\gamma$ is a pleiotropic cytokine that plays a role in the modulation of many aspects of the immune response. Studies conducted involving IFN $-\gamma-/-$ mice suggest that this cytokine, in addition to its pro-inflammatory functions, might be important for graft acceptance, preventing early graft necrosis, and maintaining microvascular viability [52,53]. However, the molecular mechanisms through which IFN- $\gamma$ exerts its anti-inflammatory action during the early phases of the engraftment are unclear. On the other hand, this interferon is considered a central cytokine in sustaining inflammation during allograft rejection both in humans and in murine models.

IFN- $\gamma$ is predominantly produced by NK cells as part of the innate immune response, and by CD4 T helper 1 cells (Th1) and CD8 cytotoxic T cells (CTLs) as a part of the adaptive immune response once antigen-specific immunity develops $[54,55]$. Its overexpression has also been observed in acute allograft rejection in several human studies where RT-PCR was applied [17,56-58]. Microarray studies have not only enabled the detection of the expression of the IFN- $\gamma$ gene itself, but also the detection of its downstream effects (IFN- $\gamma$ stimulated genes) $[15,17,21-24,59]$. Figure $1 \mathrm{~A}$ represents the first network generated by IPA after analysis of the compiled list of key immune-related genes (Table 1), with IFN- $\gamma$ serving as the hub of this important network. Detection of IFN- $\gamma$ stimulated genes alone is not sufficient to discriminate its effect from the effects of other cytokines, such as IFN- $\alpha$, which can also activate many of the IFN- $\gamma$ stimulated genes $[60,61]$. However, the prevalence of IFN- $\gamma$ versus IFN- $\alpha$ transcripts in addition to the activation of pathways that specifically enhance the INF- $\gamma$ loop (e.g. TNF- $\alpha$, CCR5, and CXCR3) implicate IFN- $\gamma$ as a driver gene involved in sustaining acute allograft rejection [22,24,26,31,59,62]. Although some functions have been described for individual IFN- $\gamma$ stimulated genes, the overall orchestration is not completely understood. A partial description of the relationship among IFN- $\gamma$ stimulated genes detected in microarray studies is illustrated in Figure 1A.

Primarily through interferon regulatory factor 1 (IRF$1)$, IFN- $\gamma$ upregulates both MHC class I and II, by increasing the expression of antigen peptide transporters TAP1-2, or class II transactivator CIITA, for example $[54,63,64]$. Indeed, IFN- $\gamma$ promotes the differentiation of naïve CD4 T cells into Th1 cells which are, among the lineage of CD4 T cells (Th1, Th2, Th17 and T Reg), the only ones that produce a consistent amount of IFN- $\gamma$ 


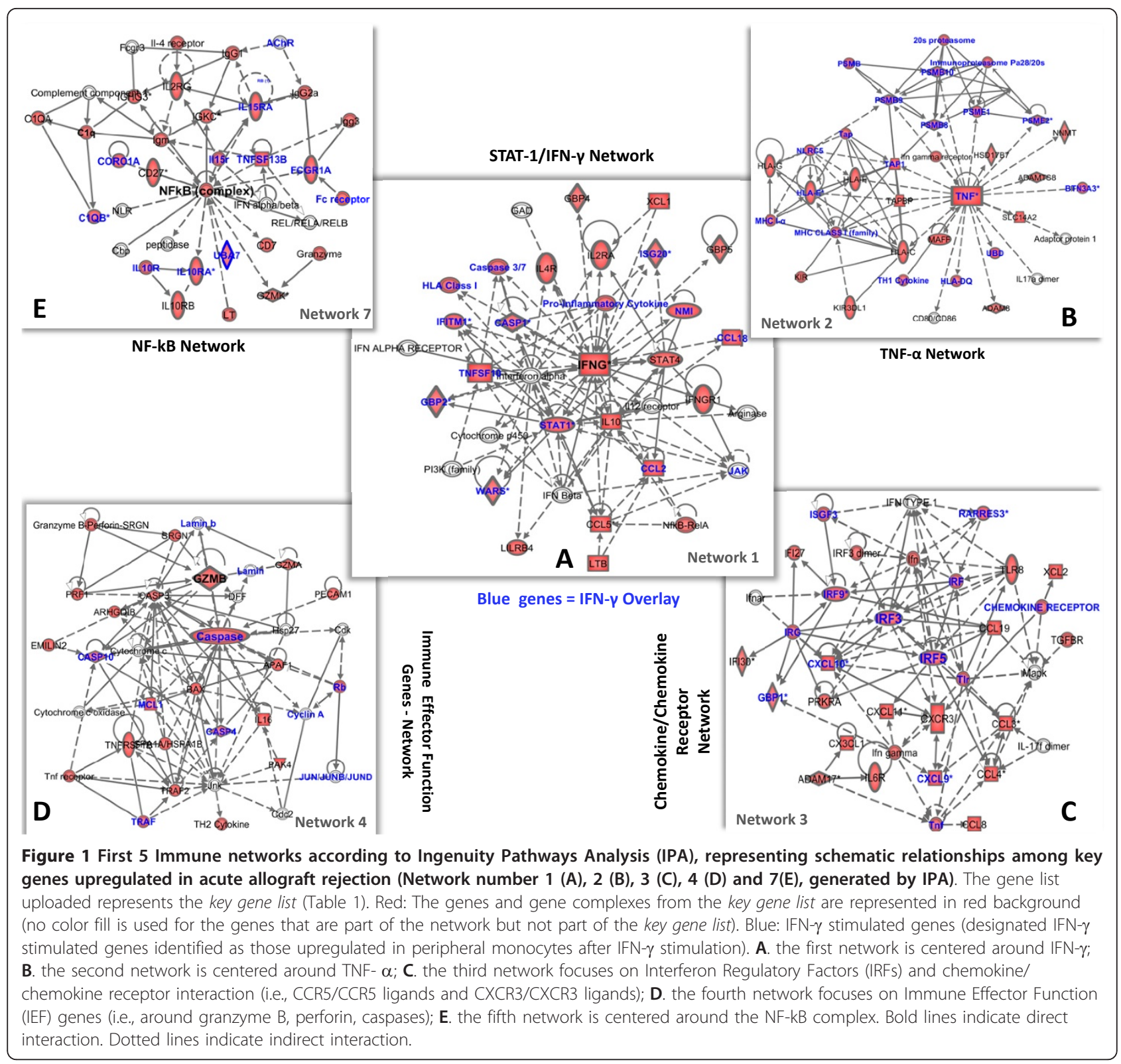

$[55,65]$. IFN $-\gamma$ in turn, and usually in synergy with tumor necrosis factor- $\alpha$ (TNF- $\alpha$ ), induces the expression of CXCR3 ligands $[54,66,67]$ and CCR5 ligands [68].

\section{CXCR3 and CCR5 ligand pathways}

CXCR3 ligands (CXCL9, -10, -11) and CCR5 ligands (CCL3, $-4,-5)$ are the chemokines most frequently upregulated during acute allograft rejection as described by human microarray studies [18,21-27] and RT-PCR (See Table 1). The upregulation of the related receptors, CXCR3 and CCR5, has also been frequently described, though not as much specifically within microarray studies [17,22,24,69-72]. Interestingly, high urinary CXCR3 ligand protein levels were detected in clinical trials in patients experiencing acute kidney rejection [48-51]. More recently, Chen et al. [27] described CXCL9 as a biomarker of acute rejection in a cross-organ microarray study evaluating pediatric renal, adult renal, and adult cardiac transplant patients. Additionally, CXCL9 proteins were also found to be elevated in serum. Indeed, the CCR $5 \Delta 32$ polymorphism that encodes for a nonfunctional CCR5 receptor, conferred a greatly reduced risk for the development of acute rejection in kidney [73] and in liver transplantation [74].

The driving role of these two pathways in allograft rejection was suggested by in vivo murine models one decade ago [75-78]. The lack of host CCR5 was associated with a three-fold increase in allograft survival 
rate, but the targeting of any of the three main ligands using knockout mice or monoclonal antibodies had no effect on allograft survival [79]. Similarly, lack of CXCR3 led to graft acceptance indefinitely [75] and in addition, a significant survival benefit has been observed in CXCL10 -/- recipients [76]. This supposed non-redundant effect of CXCR3 that has been assumed correct for almost ten years, is currently object of debate [80]. Recently, in fact, two independent studies reported that disruption or blockade of recipient CXCR3 had relatively little effect on rejection [81-83]. These observations, as well as the abundance of CXCR3 ligands present during acute allograft rejection, raise questions about the functional importance of CXCR3 during rejection and the possibility of alternative targets of CXCR3 ligands [80].

Upon antigen stimulation, the co-expression of CXCR3 and CCR5 is a marker of Th1 cell polarization, whereas CCR3, CCR4, CCR8, and CRTh2 are expressed by Th2 cells [65]. The genes and gene pathways frequently overexpressed during acute allograft rejection are consistent with the predominance of Th1 cell polarization. Among CXCR3 and CCR5 ligands, CXCL9, -10 and CCL4, -5 were the most frequently reported chemokines associated with acute rejection in microarray studies [19,21-24,31] (see Table 1).

CCR5 and CXCR3 ligands can be secreted differentially by dendritic cells, activated macrophages and $\mathrm{T}$ cells, endothelial cells, and NK cells $[69,70,84-87]$. However, studies that define the cell-specific production of chemokines in allograft rejection in humans are scant. Consequently, evidence-based descriptions of cell-specific chemokine-mediated recruitment have not been well-defined in humans either.

Hoffmann et al. [88] described that a significant proportion of both CD4+ and CD8+ T-cells detected in human renal biopsies during rejection express CXCR3. It has also been speculated that CXCR3 may act as a decoy receptor by binding CCL11, preventing the recruitment of granulocytes via the CCL11/CCR3 binding interaction $[80,89]$. This might explain why granulocytes are not classically found in acute cellular rejection. Furthermore, peripheral blood monocytes that are lower in CCR5 expression could be recruited through CCR1 that also binds CCL-3, $-4,-5$. In addition to Th1 and CTL cells, NK cells could also possibly be recruited through this pathway since they are all known to express CXCR3 and CCR5 receptors [85]. However, NK cells are rarely present in allograft infiltrates and are especially rare in T-cell mediated rejection [39,90].

Recruitment and activation of CCR5 and CXCR3 ligands can lead to increased production of IFN- $\gamma$, with a resultant amplification of the inflammatory stimuli and further release of chemoattractant molecules. Thus, in a concerted fashion, these molecules orchestrate the switch from innate to adaptive immunity, meanwhile sustaining and strengthening the innate cytotoxic mechanisms with a persistent "NK-like" response.

Finally, even though up to $25 \%$ of circulating B cells express CXCR3 [90-92], and can also produce CXCR3 ligands $[87,93]$, the recruitment of $B$ cells through this mechanism during acute allograft rejection has not yet been defined in humans.

This complex cascade of cytokines and the coordinate activation of specific pathways so far described, leads to the activation of IEF genes (perforin, granzymes A/B, Fas/Fas ligand, and caspases) during the process of tissue destruction.

\section{IEF genes}

The release of granzymes, perforins, and granulysin and the interaction between the Fas/Fas ligand and caspase activation represent the major effector mechanisms of cell-mediated immunity [94]. These IEF transcripts have been consistently described as being associated with acute allograft rejection using transcriptome analyses $[17,22,23,26]$.

By profiling PBMCs, Hidalgo et al. [40] found that cytotoxic molecular transcripts (i.e. granzyme B, Fas ligand, perforin) are commonly overexpressed in CTL CD4+ cells, CTL CD8+ cells, and NK cells. These observations highlight the existence of a common molecular cytotoxic "NK-like" effector mechanism that is shared among the different arms of the immune system, the classically distinct innate and adaptive immune arms. Taking this one step further, Mueller et al. [31] found that gene expression patterns of T-cell mediated rejection are surprisingly similar to the expression patterns found in antibody-mediated rejection. In particular, interferon- $\gamma$ affected transcripts and IEF genes such as perforin, granzyme $B$, and Fas ligand were overexpressed in both of them. This observation suggests that effector $\mathrm{T}$ cells and antibodies lead to the activation of a common final pathway in tissue destruction and supports the proposed theory of the immunologic constant of rejection [3].

\section{NK cell, B cell, and T-reg signatures NK signature}

NK cells in murine skin and rat liver allografts are the immune cells responsible for early chemokine production of CCR5 and CXCR3 ligands (i.e., CCL3, CCL4, CXCL10) which are important in initiating and sustaining acute allograft rejection $[95,96]$. Nevertheless, NK cells do not seem to be sufficient to reject solid organs directly since mice that have intact NK cell function but absent adaptive immunity ( $\mathrm{RAG}^{-1-}$ or SCID) are able to accept skin and cardiac graft transplants indefinitely [97-99]. However, the inability to reject the graft does 
not prove that innate cells (in this case NK cells) are unable to mediate tissue destruction. A possible explanation could be that, in these models, the lack of stimuli derived from a reciprocal feedback between innate and adaptive cells, does not allow triggering or sustaining a strong enough "NK-like" cytotoxic effector function.

Recently it has been observed that nude mice treated with oncolytic viruses can reject tumor xenografts [100]. This rejection was associated with the activation of ISGs (both IFN- $\gamma$ and IFN- $\alpha$ stimulated genes), upregulation of CXCR3 and CCR5 ligands, and activation of IEF genes (granzyme $\mathrm{B}$, caspase 8 ). Since these mice lack $\mathrm{T}$ cells and secondarily lack B cell responses, this immunemediated tissue destruction is thought to be induced by innate immune effectors such as NK cells and activated macrophages. This study suggests that, at least in this model, innate immunity can be an independent effector of tissue-specific destruction not requiring adaptive immunity. It is possible that the oncolytic virus used in this model primes the innate immune system in a manner that bypasses the need for the adaptive immune system interaction.

In humans, however, studies analyzing the individual contribution of innate immune cells in mediating the final step of the alloresponse are lacking. Although NK cells are present, they are only a minor component of allograft tissue infiltrates in acute rejection $[98,101,102]$. For this reason they are traditionally thought to exert only a marginal role. Therefore, the study conducted by Hidalgo et al. [39] was remarkably revealing. The investigators compared the gene expression profiles of antibody-mediated rejection in humans by analyzing the gene expression profiles in biopsies from patients with donor specific antibody. In these antibody-mediated rejection samples there was a strong expression of IFN- $\gamma$ associated transcripts and NK cells. Immunohistochemical staining displayed more NK cells and macrophages in antibody-mediated rejection than in T-cell-mediated rejection. These findings suggest that the frequent observation of IEF gene upregulation not only during $\mathrm{T}$ cell mediated rejection but also during antibody mediated rejection could reflect the activation of common "NK-like" effector functions. Recently, tolerant patients have been found to have an expansion of NK cells and overexpression of NK transcripts in peripheral blood. These findings helped generate new hypotheses on the role of NK cells in balancing tolerance and mediating rejection [103].

\section{$B$ cell signature}

The precise role that B cells play in acute allograft rejection is still being discovered. Recent high-throughput studies have exposed the multi-faceted role of B cells within allografts. With some evidence to suggest a significant role for $\mathrm{B}$ cells in mediating rejection, other evidence also suggests a role for B cells in tolerance. The $B$ cell is an enigma and the details of its functions must be further elucidated.

In a breakthrough paper in 2003, Sarwal et al. [22] found an enrichment of $B$ cell transcripts in pediatric renal biopsies experiencing acute rejection. This unexpected B-cell signature was also confirmed by immunohistochemistry. Although ectopic germinal center formation with B-cell activation and plasma cell activation can occur locally in chronically inflamed tissue $[104,105]$, the in situ presence of B cells was not historically reported in acute allograft rejection $[22,106,107]$. This $\mathrm{CD} 20+\mathrm{B}$ cell infiltration was not associated with intra-graft $\mathrm{C} 4 \mathrm{~d}$ deposition (required by Banff criteria for diagnosis of acute antibody-mediated rejection) [108] or with the detection of donor-specific antibodies, indicating that it was not necessarily related to the presence of humoral response. The presence of such CD20+ dense clusters in a significant proportion of samples from patients diagnosed with acute allograft rejection would, thereafter, be confirmed by several independent studies [109-116], with incidence varying from $15 \%$ to $60 \%$ $[38,113,116]$. However, the correlation with poor outcome suggested by Sarwal et al. [22] was confirmed by some studies $[112,114,115,117]$ but not by others $[38,109-111,113]$ and seemed more likely associated with late inflammation in allograft rejection [38]. B cell transcripts have also been detected to be upregulated during acute rejection in lung and heart transplants (Table 1) $[17,25]$.

The subsequent lineage analysis revealed that CD27+ and chronically activated CD79+, CD20+ B cells expressed HLA antigens and were surrounded by CD4+ T cells. This suggests a putative role for these cells in antigen presentation, driving a T-cell dependent cellular rejection [118]. Another cluster of B cells was represented by CD138+ mature plasma cells [118]. Recently, studies conducted in heart transplantation models showed that a deficiency in $\mathrm{B}$ cell mediated antigen presentation leads to lack of CD4 T cell activation and alloantibody production [119]. Other in vivo observations pointed to the possible pivotal role of $\mathrm{B}$ cells in the context of pathogen- $[120,121]$ or autoimmune- [122] induced $\mathrm{T}$ cell response. Interestingly, B cell infiltrates have been associated with favorable outcome in early breast cancer patients [123]. However, in addition to functioning as antigen presenting cells, B cells may promote $\mathrm{T}$ cell mediated rejection by producing chemoattractant molecules such as CXCR3 ligands (CXCL9, -10, -11) [87].

Despite the elegant rationale behind the use of an anti-CD20 monoclonal antibody (rituximab) in transplantation, this treatment showed only partial efficacy when tested in randomized trials [124-126]. Although rituximab depletes CD20+ CD27- naïve and CD20+ CD27+[127] memory cells, it is not active on plasma cells that are CD20- and are thought to be implicated in 
the pathophysiology of acute antibody-mediated rejection. Additionally, two high-throughput studies evaluating several parameters in peripheral blood $[103,128]$ and urine [128] of patients with drug-free spontaneous renal allograft tolerance found an expansion of B-cells in peripheral blood, confirming a previous report [129]. The particular phenotype of these B cells seems to be represented by an expression of memory activated B-cells and increased expression of inhibitory molecules [130]. These observations could explain the increased rate of rejection reported in rituximab-treated patients in a recent randomized controlled trial that was forced to stop prematurely [126]. With B-cells implicated in both rejection and in tolerance, their precise functions remain puzzling.

\section{T-reg signature}

The recent detection of the association between the transcription factor forkhead box 3 (FOXP3) transcripts and acute rejection deserves comment. The recruitment of CD25+, FOXP3+ T regulatory cells (T-regs) is a welldefined mechanism for controlling autoimmunity in humans and animal models. It is known that humans carrying X-linked FOXP3 mutations manifest an autoimmune syndrome consisting of immune dysregulation, polyendocrinopathy and enteropathy, termed IPEX syndrome. Additionally, FOXP3 knockout mice manifest severe autoimmune diseases as well [131,132]. However, the presence of FOXP3+ cells and/or the expression of FOXP3 are not always associated with a decreased immune response and their biological significance remains unclear. Interestingly, the pre-treatment presence of FOXP3 + T cells was associated with favorable outcome in colon cancer patients undergoing chemotherapy or immunochemotherapy [133,134]. In kidney transplantation, however, higher FOXP3 transcripts in cells obtained from urine samples was associated with acute rejection [135]. Additionally, in another study, FOXP3 expression was found to be higher in antibody-mediated and T-cell mediated acute rejection samples than it was in the non-rejection samples [136]. Since FOXP3 mRNA directly correlated with post-transplantation time the authors speculated that FOXP3 positive cells possessed the key to control the potential for autoimmunity in these sites rather than representing a cognate immune-response. Nevertheless, it is presently unclear if FOXP3 (acting as a transcription factor) can modulate the immune-response per se through unknown independent pathways.

\section{TNF- $\alpha$, Complement and IL-10: the link between the innate and adaptive immunity TNF- $\alpha$}

The upregulation of the TNF- $\alpha$ pathway is another signature often associated with acute allograft rejection (Table 1, Figure 1B). Many of the genes expressed during allograft rejection are associated with innate immunity: TNF- $\alpha$, ubiquitin, C3, Heat shock protein 70 (HSPA1A, which is the endogenous ligand of Toll-like receptor (TLR)-4) $[137,138]$ and IRF-9 (a protein that interacts with STAT-1 and STAT-2 to form ISGF3, a transcription factor for IFN- $\alpha$ ) $[139,140]$.

The presence of TNF- $\alpha$ is not indicative of acute inflammation, and it is typically also present in chronic inflammation $[3,141,142]$. Although the transformation from an indolent process to an acute one is unknown, it seems plausible that an innate stimulus that leads to increased TNF- $\alpha$, could help elicit a cascade of events associated with acute response [3]. Rather than the increase of TNF- $\alpha$ per se, these stimuli could produce a series of interconnected events, of which TNF- $\alpha$ upregulation might be one of the consequences. For example, the engagement of toll-like-receptors (TLRs) by the endogenous danger-associated molecules (the rise of which can be caused by the intervention itself or by the ischemic-reperfusion injury) $[97,143]$, may lead to NFkB (nuclear factor kappa B) activation and transcription of NF-kB induced genes, including TNF- $\alpha$ [144]. TNF- $\alpha$ is a potent activator of NF-kB, thereby amplifying a positive feedback mechanism. Moreover, NF-kB, by inducing transcription of CXCR3 and CCR5 ligands [144], could trigger and sustain the IFN- $\gamma$ cascade by promoting the migration of IFN- $\gamma$-producing Th1 cells, cytotoxic T cells, and NK cells. Concurrently, the activation of TLRs on antigen presenting cells (APCs) could also enhance antigen presentation and induce upregulation of co-stimulatory molecules, promoting adaptive responses and recruiting CTLs [145,146], with further amplification of the immune response.

In allograft rejection, the continuous and abundant availability of antigens from the surface of donor cells, and the interaction with $\mathrm{T}$ and possibly with $\mathrm{B}$ cells (directly through interaction of $B$ cell receptor and MHCs) cause a labile condition particularly vulnerable to being switched to a destructive acute response. Thus, whether this condition is sufficient per se to determine an acute response (according to the self non-self model) or needs to be prompted (in accordance with the danger model), is object of ongoing debate $[137,147]$.

In conclusion, we could hypothesize that both innate and adaptive mechanisms synergize in generating/sustaining the immune response. Indeed, the dual presence of such strong stimuli leads almost inevitably to a progressive destructive response, thereby requiring lifelong immunosuppression, with the exception of the rare cases of spontaneous tolerance $[103,128,148]$.

\section{Complement}

Complement is the archetypal innate defense mechanism and provides a vital link between innate and adaptive functions [149-151]. Briefly, the central event in 
complement activation is the proteolysis of C3 (activated by antibodies or microbial cell surfaces) to generate biologically active products that lead to the formation of membrane attack complexes that result in the activation of granulocytes and cell lysis [149-151]. The majority of complement is synthesized in the liver; however, local sources of complement include endothelial cells, macrophages, neutrophils, and epithelial cells (particularly renal tubular epithelial cells). The molecular pathways that lead to the activation of complement transcription during the alloresponse are not completely clear, but activation of the NF-kB pathway has been suggested to be a potential stimulus for local C3 production [152,153]. It has been proposed that C3 could also be responsible for the Th1 response observed during allorejection, directly by sustaining Th1 development [154], or indirectly by inhibiting Th2 polarization [155]. Priming C3 deficient mice with dendritic cells led to delayed skin allograft rejection. Additionally, complement can activate B cells and initiate humoral responses [156]. In kidney transplantation in animal models, it has been shown that local renal C3 production leads to faster allograft rejection $[157,158]$. However, opposing results were reached in three independent studies analyzing liver transplantation in animal models. In these cases, an association between overexpression of C3 and tolerance was found [159-161]. Thus, at least in animal models, it is possible to hypothesize the existence of diverse regulatory mechanisms in different organs.

The presence of $\mathrm{C} 4 \mathrm{~d}$ (a C4 split product) by immunohistochemical staining is a feature associated with antibody-mediated rejection since it can activate the classical pathway of complement. Since the majority of circulating complement is produced by the liver, complement is not typically detected by microarray analysis. Thus, detection of complement transcripts during acute allograft rejection by gene expression suggests local production within the graft.

C3 and/or other complement components (C1 and C4) have been associated with acute allograft rejection in several microarray studies conducted in renal [23,21], liver [15], heart [19,25], and lung [17] transplants. Currently, interest in the role of complement in the regulation of the alloresponse is rising $[149,150,162]$. In a recent study conducted by Naesens et al. (Stanford group [162]), the authors observed upregulation of complement genes before transplantation in deceased donor kidney biopsies compared to living donors. In the same publication, the authors reported a significant overexpression of genes involved in the complement cascade (including $\mathrm{C} 1$ and $\mathrm{C} 3$ ) when comparing 32 acute rejection samples to 20 non-rejection samples obtained from pediatric kidney recipients [162].

\section{IL-10}

Contrary to the popular belief that IL-10 is principally an anti-inflammatory cytokine, the IL-10 pathway is frequently described as upregulated during acute allograft rejection in kidney and liver transplants in humans $[14,23,26]$ (Table 1).

Although the canonical effects of IL-10 are regulatory and function in the termination of inflammatory processes [163], this cytokine cannot merely be classified as anti-inflammatory, due to its pleiotropic ability to both positively and negatively influence the function of innate and adaptive immunity in pre-clinical models [164-166]. In humans, intravenous administration of recombinant IL-10 produces pro-inflammatory effects by enhancing the release of IFN- $\gamma$, TNF- $\alpha$, and IL-1, and appears to induce the activation of CTLs and NK cells, as reflected by increased plasma levels of granzyme-B $[167,168]$. Interestingly, high levels of serum IL-10 were associated with anti-tumor response in a clinical trial involving metastatic melanoma patients treated with immunochemotherapy (i.e., bevacizumab and fotemustine) [169]. In human monocyte lineage cells, IL-10 increases the expression of TLRs, which might sensitize these cells to 'danger signal' mediators. This suggests that IL-10 plays a key role in the early phases of the acute immune response. Systemic administration of IL-10 exacerbates alloreactions in murine models $[170,171]$, and, accordingly, the administration of anti-IL-10 monoclonal antibody prolongs graft survival [172]. In addition, by inhibiting APC maturation and postponing their migration to lymph nodes, this cytokine may lead to more efficient antigen loading, and might activate locally adaptive effectors [164-166]. In humans, post-transplant levels of IL-10 [173] and a specific IL-10 polymorphism [174] were associated with risk of acute rejection in kidney transplants.

The evidence provided supports IL-10 involvement in tumor rejection and allograft rejection in humans, and suggests that this cytokine defies its reputation of having solely anti-inflammatory properties.

\section{IRF-1 and STAT-1}

By using MetaCore algorithms, IRF-1 and STAT-1 were predicted to be regulators of several of the key transcripts after analysis of our key genes list extracted from microarray studies (Figure 2). IRF-1 is an inducible IFN$\gamma$ transcription factor and it is transcribed in response to IFN- $\gamma$ via STAT-1 [54,175]. This transcription factor could mediate the upregulation of several gene/gene pathways during acute allograft rejection, as shown in Figure 2. Genes upregulated by IRF-1 include proinflammatory cytokines (e.g. TNF- $\alpha$ [176]), chemokines (e.g. CXCL10 [66,67], CCL5 [68]), and MHC class I and class II molecules $[54,177]$. It could also drive the synthesis of IL-10 RA [66]. Another important pro- 


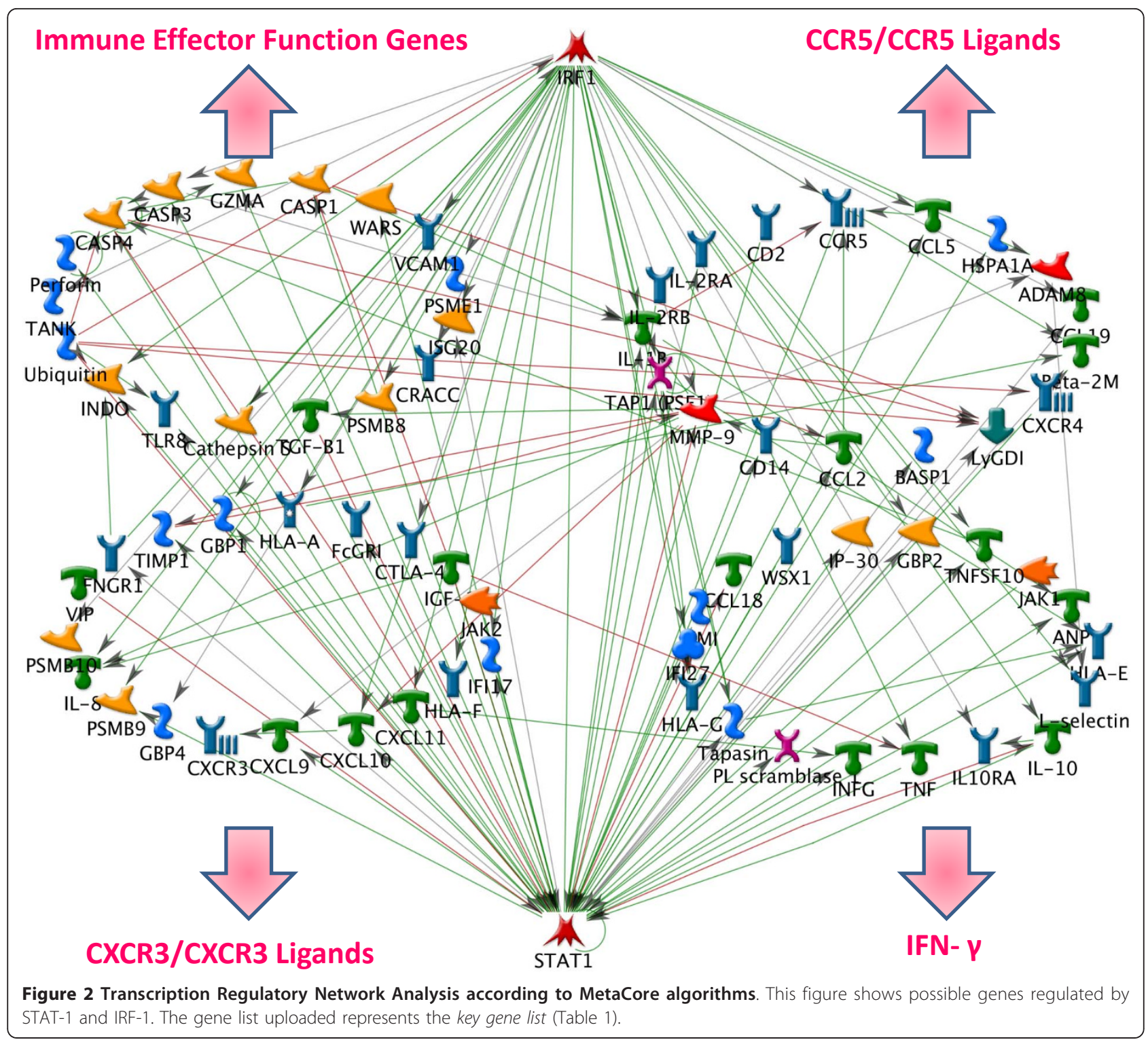

inflammatory function of this gene is the induction of IL-12 [178] and IL-15 [179] with consequent enhancement of the IFN- $\gamma$ cascade.

IRF-1 has been better described with relation to tumor rejection. In a study conducted in melanoma patients by Wang et al. [2], IRF-1 was the most significantly and consistently upregulated transcript in metastatic melanoma lesions undergoing clinical regression after the systemic administration of high-dose interleukin-2. IRF1 appeared to play a central role in orchestrating the immune response, generating the switch from chronic to acute inflammation in this as well as several subsequent studies [3,4].

Regarding the allograft, although statistical algorithms recognize IRF-1 as one of the main transcription factors that regulate genes involved in acute allograft rejection, it should be noted that its overexpression per se has not yet been identified as relevant according to human microarray studies. Thus, these data must be interpreted cautiously. Nevertheless, STAT-1 has been massively described as upregulated during acute allograft rejection (see Table 1), suggesting the regulation of IRF-1 through the IFN- $\gamma /$ STAT- 1 pathway as a plausible mechanism. In a recent mouse liver transplant model microarray study, IRF-1 was one of the two genes overexpressed both in leukocytes and intragraft during acute cellular rejection (GBP2 was the other gene, also an IFN- $\gamma$ inducible gene) [180]. Accordingly, studies have reported an association between IRF-1 and acute cellular rejection in heart transplant models $[181,182]$. On the other hand, other groups have reported STAT-1/IRF-1 pathway to be upregulated in tolerant models $[159,160]$. In order to 
explain these findings, investigators proposed the induction of $\mathrm{T}$ cell apoptosis by IFN- $\gamma$ signaling [159]: the transcripts STAT-1 and IRF-1 were also found to be involved in the induction of apoptosis via a caspasemediated mechanism [183] (Figure 2). Thus, it is likely that IRF-1 plays a different role according to the independent co-activation of different pathways, which can greatly differ from cell to cell but can also vary with changes in the surrounding environment [183].

Although IRF-1 seems to be regulated primarily by IFN- $\gamma$ signaling [175], in vivo and in vitro observations suggested that IRF-1 regulation does not necessarily require the interaction of this cytokine. Indeed, IRF-1 has been observed in response to IL- 2 stimulation in vitro [184] and in the absence of interferon upregulation in animal models [100]. In addition, IRF- $1^{-/}$mice have defects not observed in IFN- $\gamma$ or IFN- $\gamma$ - receptor ${ }^{-/-}$animals, (such as alterations in CD8+ $\mathrm{T}$ cells and thymocyte development), supporting the existence of an IFN$\gamma$-independent activation pathway of IRF-1, [54,185]. Vice versa, even supposing a central role for this protein in the induction of pro-inflammatory mediators, a recent microarray study in heart transplanted mice suggested that IRF-1 functions could be bypassed by other mediators [186]. That same study showed that the expression profile of the allograft from IRF-1 $1^{-1-}$ mice and wild type mice were nearly identical to each other and very different from the profile of isograft control.

\section{Comparative analyses}

Despite discrepancies among different studies, crosscomparison of datasets has been remarkably revealing $[25,26]$, probably because of the highly conserved molecular patterns associated with immune-mediated tissue destruction. The first comparative analysis was performed by Morgun et al. [25] who, after identifying a gene set predictive of acute-rejection in a series of heart allograft recipients, analyzed the data from two published studies on kidney (Stanford dataset [187] and Cleveland dataset [23]) and lung (Minneapolis dataset [17]) transplants. The authors observed a striking agreement with the histological diagnosis of the three studies. The predictive accuracy of the gene set obtained from studying hearts was close to $95 \%$ in kidney and lung acute rejection illustrating the similarity of activated pathways from different rejected organs. Similar to observations in renal transplants [22], B cell transcripts (immunoglobulins) were among the most upregulated, suggesting that $B$ cells may also have a local effect in heart rejection. Another interesting finding was the similar pattern of immune-response-related gene expression (antigen presentation, innate immunity, chemotaxis, immunoglobulins and cytokines) among samples with diagnosis of acute rejection versus infection. Here, the gene expression pattern of transplant recipients who underwent rejection was similar to that of patients with Trypanosoma cruzi infection (which represents a frequent cause of chronic heart failure and consequent need for heart transplant in Latin America) [25]. The similarities in inflammatory/immune expression patterns between acute rejection and infection have also been described by Sarwal et al. [22].

By utilizing an established protein prediction model for discovering serum biomarkers of disease, (Integrated RNA Data Driven Proteomics (IRDDP)), Chen et al. [27] applied this model to cross-organ acute allograft rejection datasets. In this analysis, three existing gene expression datasets were analyzed to identify candidate serum protein biomarkers. Evaluation of the three datasets revealed 45 genes commonly differentially expressed in acute allograft rejection (see Table 1). The datasets were extracted from GEO and were derived from microarray studies conducted on pediatric renal, adult renal, and adult cardiac human tissue biopsies during acute allograft rejection. Interestingly, by applying this protein biomarker prediction model, this data guided the investigators to discover three serum protein biomarkers, PECAM1, CXCL9, and CD44, that could distinguish acute rejection from stable allograft function. Notably, since gene expression data was compared in heart and kidney samples, it reinforces the principal that common molecular mechanisms exist in acute allograft rejection across different organs.

Another comparative analysis was conducted by SaintMezard et al. [26] analyzing three datasets from human renal acute allograft rejection microarray studies. These authors compared their own data, which consisted of human and non-human primate kidney acute rejection biopsy specimens, to the Stanford [22] and Cleveland [23] datasets. By doing so, the authors analyzed 36 acute rejection samples, identifying 70 genes that were upregulated during acute allograft rejection. Importantly, they successfully validated their findings by using 143 microarrays from the Edmonton dataset [31].

Using GeneGo MetaCore algorithms (a web-based suite for functional analysis of experimental data http:// www.genego.com) STAT-1, Interferon Regulatory Factor (IRF-1), Nuclear Factor Kappa B (NF-kB), and PU.1 (a transcription factor involved in the in the development of myeloid and lymphoid cells [188]) were identified as the main transcription factors that regulate the 70 genes consistently represented during kidney acute rejection in according to the Saint-Mezard comparative analysis [26]. The relationship among different protein-protein interactions, activation of transcription factors, and functional response is often difficult to establish because of its complexity and due to the incompletely understood association among signaling pathways. In simple 
terms, during the alloresponse, NF-kB represents a constitutive activation of innate immunity (e.g. TNF- $\alpha$ pathway), and IRF-1 superimposes a switch toward adaptive immunity (through the IFN- $\gamma$ pathway). As described previously, these two pathways can amplify each other, and can also collaborate in inducing the transcription of common genes. For example, IFN- $\gamma$ (through IRF-1) and TNF- $\alpha$ (through NF-kB) can synergize in promoting the overexpression of common genes such as CXCR3 ligands [67] and CCR5 ligands [144]. Figure 3 summarizes a likely reciprocal enhancement of function between the NF-kB and the STAT-1/IRF-1 pathways during allograft rejection. Beyond the function of master regulator of innate immunity, NF-kB is also important in driving the adaptive response. In fact, it plays a key role in IL-2 and TCR signaling, and in the regulation of immunoglobulin production [152]. It should be noted that most of the drugs effective in the treatment and/or prevention of acute allograft rejection (e.g. glucocorticoids, cyclosporine, and tacrolimus), interact with NF$\mathrm{kB}$ pathway, and result in reduced production of several cytokines such as IL-2 and TNF- $\alpha$ [152]. Accordingly, NF-kB activity impairment leads to an attenuation of acute rejection in heart [189-191], lung [192] and skin [193] in animal models.

\section{Metzincins and Related Genes}

Recently, attention has been brought to the role of the metzincins (a superfamily of endopeptide cleaving extracellular matrix proteins implicated in remodeling and

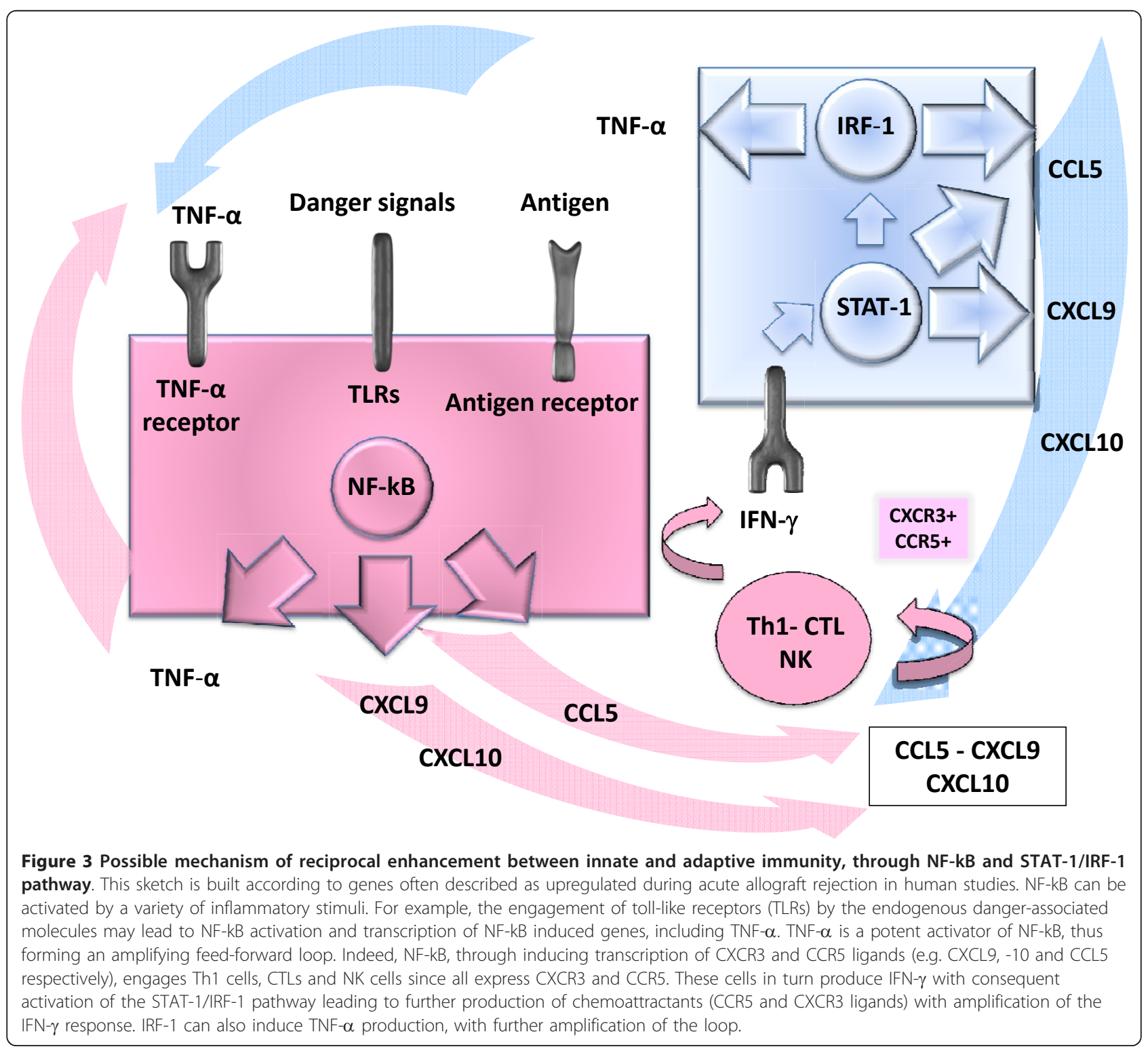


modulation of cell signaling) in acute allograft rejection. In the Rodder meta-analysis, expression of Metzincins and Related Genes (MARGs) were analyzed from four separate microarray study databases to characterize markers of acute rejection in renal transplantation $[22,23,29,31]$, revealing MMP7 and TIMP1 as the most highly upregulated genes [29]. Interestingly, MMP9, TIMP1, and ADAM genes have also been noted to be associated with liver and heart acute allograft rejection $[14,15,25]$ as listed in Table 1 of this review. Further, MMP9 and MMP2 were also described to be upregulated in a case report of small bowel acute rejection profiled by microarray. Of note, IFN- $\gamma$ was also upregulated in this case report emphasizing the similarity crossorgan in acute allograft rejection [20].

\section{Conclusions}

High-throughput gene expression profiling has emerged as a powerful and reliable tool in investigating immune response in vivo in humans $[11,12]$. Bypassing the traditional hypothesis-driven approach, microarray studies have revealed unsuspected mechanisms that mediate the balance between rejection and tolerance.

The pathways thought to be central during acute allograft rejection have been described in this review. Most of the pathways analyzed (IFN- $\gamma / \mathrm{STAT}-1 /$ IRF- 1 path, CXCR3/CXCR3 ligands path, CCR5/CCR5 ligands path, and IEFs path) have also been associated with other immune-mediated processes, strengthening the concept that there are common convergent molecular mechanisms in tissue specific destruction, as described by the Immunologic Constant of Rejection [3,194-198]. Even if the pathways analyzed are consistently observed in humans, previous experiments in animal models failed to demonstrate them as necessary or sufficient for the development of rejection, in concordance with the high redundancy of mammalian immune system $[54,82,83]$. Moreover, some of the genes associated with acute rejection also seem to play a role in tolerance models (e. g.STAT-1/IRF-1 $[159,160])$, stressing the pleiotropism of such molecules, as well as illustrating the complexity of these networks and the necessity of investigating immune-response mechanisms in vivo in humans. Despite the wide-ranging observations at molecular level which could be significantly influenced by multiple factors including sample collection time, sample type, sample handling and storage conditions, patient physiological condition, coexisting pathological conditions, environmental factors and genetic predisposition, distinct molecular patterns associated with tissue destruction have been revealed and summarized in this review.

In conclusion, the purpose of this review was to contribute to the understanding of how tissue specific destruction occurs. Understanding why this occurs is one of the most challenging and intriguing questions facing modern human immunology.

\section{Additional material}

\begin{abstract}
Additional file 1: supplemental data extraction information
supplemental information for key gene selection used for Table 1, IPA and Meta Core analysis. Comprehensive lists of relevant upregulated genes, in according with the original publication, are reported for the following studies: Akalin et al, Tannapfel et al, Sreekumar et al, Karason et al (genes most frequently upregulated during the rejection episode and returned to baseline levels with its resolution), Reeve et al (genes most frequently represented in the predictive analysis for microarrays classifier), Saint-Mezard et al. Morgun et al: we reported the upregulated genes selected from the list of 98 genes belonged to the first predictor set that discriminate acute cardiac, renal and lung rejection from non rejection. CCL5 belonged to the second prediction set. Sarwal et al: we selected key immune genes from the list of genes upregulated in three different subtypes of acute allograft rejection (see also Mansfield et al. 2004 and Weintraub et al 2006). Gimino et al and Lande et al: we selected key genes from a list of genes reported as upregulated during acute rejection according to the first (Gimino et al) and second (Lande et al) analyses. Flechner et al: we selected key genes a list of genes upregulated in acute rejection samples compared to samples without diagnosis of rejection. Others upregulated genes included in the original list were: Morgun et al: Homo sapiens CDNA FLJ10266 fis, clone HEMBB1001024; Homo sapiens CDNA FLJ10580 fis, clone NT2RP2003533, mRNA sequence; Homo sapiens CDNA FLJ10981 fis, clone PLACE1001610; Homo sapiens mRNA, cDNA DKFZp434P1019; Homo sapiens mRNA; cDNA DKFZp564P073; Homo sapiens mRNA; cDNA DKFZp586H0718; Homo sapiens mRNA; cDNA DKFZp761G0924; Homo sapiens mRNA; CDNA DKFZp761P221; DKFZP434B033; Unknown (protein for

IMAGE:4251653) [Homo sapiens], mRNA sequence; Unnamed protein product [Homo sapiens]. Karason: Homo sapiens Alu repeat (LNXI) mRNA sequence. Reeve et al: affymetrix id 235529_at and 238725_at. The 14 genes selected in the Inkinen et al study were those genes highly upregulated in AR vs NR control. Morgun et al: we reported the upregulated genes selected from the list of 98 genes belonged to the first classifier that discriminate acute cardiac rejection vs non rejection and immune-related genes selected from the second and third classifier (130 and 188 genes respectively): the three classifier also discriminated rejection and non rejection lung and kidney samples. Asaoka et al analyzed biopsies from 21 liver transplant recipients with recurrent $\mathrm{HCV}$ (RHC). Analysis compared 9 with $\mathrm{AR}+\mathrm{RHC}$ versus 13 with $\mathrm{RHC}$ only (control). Genes shown in this table selected from the network classified as "Cell death, hematological disease, and immunological disease" via IPA.
\end{abstract}

\section{Acknowledgements}

Tara Spivey's research fellowship was made possible through the Clinical Research Training Program, a public-private partnership supported jointly by the NIH and Pfizer Inc. (via a grant to the foundation for NIH from Pfizer Inc.). Davide Bedognetti is a participant in the NIH Graduate Partnership Program and a graduate student at University of Genoa. Davide Bedognetti's fellowship is supported by the Conquer Cancer Foundation of the American Society of Clinical Oncology (2011 Young Investigator Award). Davide Bedognetti thanks Dr. Pietro Blandini (U.C. Sampdoria, Genoa, Italy) for his useful suggestion on multidimensional data analysis.

\section{Author details}

${ }^{1}$ Infectious Disease and Immunogenetics Section (IDIS), Department of Transfusion Medicine, Clinical Center and trans-NIH Center for Human Immunology (CHI), National Institutes of Health, Bethesda, Maryland, 20892, USA. ${ }^{2}$ Clinical Research Training Program (CRTP), National Institutes of Health, Bethesda, Maryland, 20892, USA. ${ }^{3}$ Rush University Medical Center, Rush Medical College, Chicago, Illinois, 60612, USA. ${ }^{4}$ Luigi Sacco Hospital, Via G.B. 
Grassi, 20157 Milano, Italy. ${ }^{5}$ Department of Internal Medicine (DiMI), University of Genoa, Viale Benedetto XV, 6, 16132 Genoa, Italy. ${ }^{6}$ Center of Excellence for Biomedical Research (CEBR), University of Genoa, Viale Benedetto XV, 6, 16132 Genoa, Italy. 'Laboratory of Molecular Pharmacology, Center for Cancer Research, National Cancer Institute, National Institutes of Health, Bethesda Maryland, 20892, USA. ${ }^{8}$ University of Sassari, Department of Drug Sciences, Via Muroni 23 A, 07100, Sassari, Italy. ${ }^{9}$ Department of Oncology, Biology, and Genetics, University of Genoa, and National Cancer Research Institute, Largo Rosanna Benzi 10, 16132 Genoa, Italy.

\section{Authors' contributions}

DB and TLS performed data extraction from the available literature and prepared the manuscript collaboratively with input and review by all coauthors. FMM and EW reviewed data extraction and literature research and revised the manuscript for important intellectual contents. All authors read and approved the final manuscript.

\section{Competing interests}

The authors declare that they have no competing interests.

Received: 4 May 2011 Accepted: 12 October 2011

Published: 12 October 2011

\section{References}

1. Panelli MC, Stashower ME, Slade HB, Smith K, Norwood C, Abati A, Fetsch P, Filie A, Walters SA, Astry C, et al: Sequential gene profiling of basal cell carcinomas treated with imiquimod in a placebo-controlled study defines the requirements for tissue rejection. Genome Biology 2007, 8.

2. Wang E, Miller LD, Ohnmacht GA, Mocellin S, Perez-Diaz A, Petersen D, Zhao YD, Simon R, Powell Jl, Asaki E, et al: Prospective molecular profiling of melanoma metastases suggests classifiers of immune responsiveness. Cancer Research 2002, 62:3581-3586.

3. Wang $E$, Worschech A, Marincola FM: The immunologic constant of rejection. Trends in Immunology 2008, 29:256-262.

4. Bedognetti D, Wang E, Sertoli MR, Marincola FM: Gene-expression profiling in vaccine therapy and immunotherapy for cancer. Expert Review of Vaccines 2010, 9:555-565.

5. Imanguli MM, Swaim WD, League SC, Gress RE, Pavletic SZ, Hakim FT: Increased T-bet+ cytotoxic effectors and type I interferon-mediated processes in chronic graft-versus-host disease of the oral mucosa. Blood 2009, 113:3620-3630

6. He XS, Ji X, Hale MB, Cheung R, Ahmed A, Guo Y, Nolan GP, Pfeffer LM, Wright TL, Risch $N$, et al: Global transcriptional response to interferon is a determinant of HCV treatment outcome and is modified by race. Hepatology 2006, 44:352-359.

7. Feld JJ, Nanda S, Huang Y, Chen W, Cam M, Pusek SN, Schweigler LM, Theodore D, Zacks SL, Liang TJ, Fried MW: Hepatic gene expression during treatment with peginterferon and ribavirin: Identifying molecular pathways for treatment response. Hepatology 2007, 46:1548-1563.

8. Okamoto Y, Folco EJ, Minami M, Wara AK, Feinberg MW, Sukhova GK, Colvin RA, Kihara S, Funahashi T, Luster AD, Libby P: Adiponectin inhibits the production of CXC receptor 3 chemokine ligands in macrophages and reduces T-lymphocyte recruitment in atherogenesis. Circ Res 2008, 102:218-225

9. Costa C, Rufino R, Traves SL, Lapa ESJR, Barnes PJ, Donnelly LE: CXCR3 and CCR5 chemokines in induced sputum from patients with COPD. Chest 2008, 133:26-33.

10. Kim MJ, Romero R, Kim CJ, Tarca AL, Chhauy S, LaJeunesse C, Lee DC Draghici S, Gotsch F, Kusanovic JP, et al: Villitis of Unknown Etiology Is Associated with a Distinct Pattern of Chemokine Up-Regulation in the Feto-Maternal and Placental Compartments: Implications for Conjoint Maternal Allograft Rejection and Maternal Anti-Fetal Graft-versus-Host Disease. Journal of Immunology 2009, 182:3919-3927.

11. Patterson TA, Lobenhofer EK, Fulmer-Smentek SB, Collins PJ, Chu TM, Bao W, Fang H, Kawasaki ES, Hager J, Tikhonova IR, et al: Performance comparison of one-color and two-color platforms within the MicroArray Quality Control (MAQC) project. Nat Biotechnol 2006, 24:1140-1150.

12. Shi L, Reid LH, Jones WD, Shippy R, Warrington JA, Baker SC, Collins PJ, de Longueville F, Kawasaki ES, Lee KY, et al: The MicroArray Quality Control (MAQC) project shows inter- and intraplatform reproducibility of gene expression measurements. Nat Biotechnol 2006, 24:1151-1161.
13. Eikmans M, Roos-van Groningen MC, Sijpkens YWJ, Ehrchen J, Roth J, Baelde HJ, Bajema IM, de Fijter JW, de Heer E, Bruijn JA: Expression of surfactant protein-C, S100A8, S100A9, and B cell markers in renal allografts: Investigation of the prognostic value. Journal of the American Society of Nephrology 2005, 16:3771-3786.

14. Tannapfel A, Geissler F, Witzigmann H, Hauss J, Wittekind C: Analysis of liver allograft rejection related genes using CDNA-microarrays in liver allograft specimen. Transplantation Proceedings 2001, 33:3283-3284.

15. Sreekumar R, Rasmussen DL, Wiesner RH, Charlton MR: Differential allograft gene expression in acute cellular rejection and recurrence of hepatitis $C$ after liver transplantation. Liver Transplantation 2002, 8:814-821.

16. Inkinen K, Lahesmaa R, Brandt A, Katajamaa M, Halme L, Hockerstedt K, Lautenschlager I: DNA microarray-based gene expression profiles of cytomegalovirus infection and acute rejection in liver transplants. Transplantation Proceedings 2005, 37:1227-1229.

17. Gimino VJ, Lande JD, Berryman TR, King RA, Hertz MI: Gene expression profiling of bronchoalveolar lavage cells in acute lung rejection. American Journal of Respiratory and Critical Care Medicine 2003, 168:1237-1242.

18. Patil J, Lande JD, Li N, Berryman TR, King RA, Hertz Ml: Bronchoalveolar lavage cell gene expression in acute lung rejection: Development of a diagnostic classifier. Transplantation 2008, 85:224-231.

19. Karason K, Jernas M, Hagg DA, Svensson PA: Evaluation of CXCL9 and CXCL10 as circulating biomarkers of human cardiac allograft rejection. BMC CardiovascDisord 2006, 6:29.

20. Bradley BA: Prognostic assays for rejection and tolerance in organ transplantation. Transplant Immunology 2005, 14:193-201.

21. Akalin E, Hendrix RC, Polavarapu RG, Pearson TC, Neylan JF, Larsen CP, Lakkis FG: Gene expression analysis in human renal allograft biopsy samples using high-density oligoarray technology. Transplantation 2001, 72:948-953.

22. Sarwal M, Chua MS, Kambham N, Hsieh SC, Satterwhite T, Masek M Salvatierra O: Molecular heterogeneity in acute renal allograft rejection identified by DNA microarray profiling. New England Journal of Medicine 2003, 349:125-138

23. Flechner SM, Kurian SM, Head SR, Sharp SM, Whisenant TC, Zhang J, Chismar JD, Horvath S, Mondala T, Gilmartin T, et al: Kidney transplant rejection and tissue injury by gene profiling of biopsies and peripheral blood lymphocytes. American Journal of Transplantation 2004, 4:1475-1489.

24. Reeve J, Einecke G, Mengel M, Sis B, Kayser N, Kaplan B, Halloran PF: Diagnosing Rejection in Renal Transplants: A Comparison of Molecularand Histopathology-Based Approaches. American Journal of Transplantation 2009, 9:1802-1810.

25. Morgun A, Shulzhenko N, Perez-Diez A, Diniz VZ, Sanson GF, Almeida DR, Matzinger $P$, Gerbase-DeLima M: Molecular profiling improves diagnoses of rejection and infection in transplanted organs. Circulation Research 2006, 98:E74-E83.

26. Saint-Mezard P, Berthier CC, Zhang H, Hertig A, Kaiser S, Schumacher M, Wieczorek G, Bigaud M, Kehren J, Rondeau E, et al: Analysis of independent microarray datasets of renal biopsies identifies a robust transcript signature of acute allograft rejection. Transplant International 2009, 22:293-302.

27. Chen R, Sigdel TK, Li L, Kambham N, Dudley JT, Hsieh SC, Klassen RB, Chen A, Caohuu T, Morgan AA, et al: Differentially expressed RNA from public microarray data identifies serum protein biomarkers for crossorgan transplant rejection and other conditions. PLoS Comput Biol 2010, 6.

28. Asaoka T, Kato T, Marubashi S, Dono K, Hama N, Takahashi H, Kobayashi S, Takeda Y, Takemasa I, Nagano H, et al: Differential transcriptome patterns for acute cellular rejection in recipients with recurrent hepatitis $C$ after liver transplantation. Liver Transp/ 2009, 15:1738-1749.

29. Rodder S, Scherer A, Korner M, Eisenberger U, Hertig A, Raulf F, Rondeau E, Marti HP: Meta-analyses qualify metzincins and related genes as acute rejection markers in renal transplant patients. Am J Transplant 2010, 10:286-297.

30. Lande JD, Patil J, Li N, Berryman TR, King RA, Hertz MI: Novel insights into lung transplant rejection by microarray analysis. Proc Am Thorac Soc 2007, 4:44-51.

31. Mueller TF, Einecke G, Reeve J, Sis B, Mengel M, Jhangri GS, Bunnag S, Cruz J, Wishart D, Meng C, et al: Microarray analysis of rejection in human 
kidney transplants using pathogenesis-based transcript sets. American Journal of Transplantation 2007, 7:2712-2722.

32. Bunnag $S$, Einecket $G$, Reeve J, Jhangri GS, Mueller TF, Sis B, Hidalgo LG, Mengel M, Kayser D, Kaplan B, Halloran PF: Molecular Correlates of Renal Function in Kidney Transplant Biopsies. Journal of the American Society of Nephrology 2009, 20:1149-1160

33. Perco P, Kainz A, Wilflingseder J, Soleiman A, Mayer B, Oberbauer R: Histogenomics: Association of Gene Expression Patterns With Histological Parameters in Kidney Biopsies. Transplantation 2009, 87:290-295.

34. Sis B, Jhangri GS, Bunnag S, Allanach K, Kaplan B, Halloran PF: Endothelial Gene Expression in Kidney Transplants with Alloantibody Indicates Antibody-Mediated Damage Despite Lack of C4d Staining. American Journal of Transplantation 2009, 9:2312-2323.

35. Sis B, Halloran PF: Endothelial transcripts uncover a previously unknown phenotype: C4d-negative antibody-mediated rejection. Current Opinion in Organ Transplantation 2010, 15:42-48.

36. Mengel M, Reeve J, Bunnag S, Einecke G, Jhangri GS, Sis B, Famulski K Guembes-Hidalgo L, Halloran PF: Scoring Total Inflammation Is Superior to the Current Banff Inflammation Score in Predicting Outcome and the Degree of Molecular Disturbance in Renal Allografts. American Journal of Transplantation 2009, 9:1859-1867.

37. Einecke G, Mengel M, Hidalgo L, Allanach K, Famulski KS, Halloran PF: The Early Course of Kidney Allograft Rejection: Defining the Time When Rejection Begins. American Journal of Transplantation 2009, 9:483-493.

38. Einecke G, Reeve J, Mengel M, Sis B, Bunnag S, Mueller TF, Halloran PF: Expression of $B$ cell and immunoglobulin transcripts is a feature of inflammation in late allografts. American Journal of Transplantation 2008, 8:1434-1443

39. Hidalgo LG, Sis B, Sellares J, Campbell PM, Mengel M, Einecke G, Chang J, Halloran PF: NK cell transcripts and NK cells in kidney biopsies from patients with donor-specific antibodies: evidence for NK cell involvement in antibody-mediated rejection. Am J Transplant 2010, 10:1812-1822.

40. Hidalgo LG, Einecke G, Allanach K, Mengel M, Sis B, Mueller TF, Halloran PF: The transcriptome of human cytotoxic T cells: Measuring the burden of CTL-Associated transcripts in human kidney transplants. American Journal of Transplantation 2008, 8:637-646.

41. Mengel M, Chang J, Kayser D, Gwinner W, Schwarz A, Einecke G, Broecker V, Famulski K, De Freitas DG, Guembes-Hidalgo L, et al: The Molecular Phenotype of 6-Week Protocol Biopsies from Human Renal Allografts: Reflections of Prior Injury but Not Future Course. Am J Transplant 2010

42. Mengel M, Sis B, Kim D, Chang J, Famulski KS, Hidalgo LG, Einecke G, de Freitas DG, Tymchak W, Burton J, Halloran PF: The molecular phenotype of heart transplant biopsies: relationship to histopathological and clinical variables. Am J Transplant 2010, 10:2105-2115.

43. Famulski KS, Einecke G, Sis B, Mengel M, Hidalgo LG, Kaplan B, Halloran PF Defining the canonical form of T-cell-mediated rejection in human kidney transplants. Am J Transplant 2010, 10:810-820.

44. Einecke G, Kayser D, Vanslambrouck JM, Sis B, Reeve J, Mengel M, Famulski KS, Bailey CG, Rasko JE, Halloran PF: Loss of solute carriers in T cell-mediated rejection in mouse and human kidneys: an active epithelial injury-repair response. Am J Transplant 2010, 10:2241-2251.

45. Einecke G, Reeve J, Sis B, Mengel M, Hidalgo L, Famulski KS, Matas A, Kasiske B, Kaplan B, Halloran PF: A molecular classifier for predicting future graft loss in late kidney transplant biopsies. J Clin Invest 2010 120:1862-1872

46. Mengel M, Allanach $\mathrm{K}$, Einecke $\mathrm{G}$, Sis B, Hidalgo L, Mueller T, Halloran PF: Comparing microarray versus RT-PCR assessment of renal allograft biopsies: Similar performance despite different dynamic ranges. American Journal of Transplantation 2008, 8:349-349.

47. Pham MX, Teuteberg JJ, Kfoury AG, Starling RC, Deng MC, Cappola TP, Kao A, Anderson AS, Cotts WG, Ewald GA, et al: Gene-expression profiling for rejection surveillance after cardiac transplantation. N Engl J Med 2010, 362:1890-1900.

48. Schaub S, Nickerson P, Rush D, Mayr M, Hess C, Golian M, Stefura W, HayGlass K: Urinary CXCL9 and CXCL10 Levels Correlate with the Extent of Subclinical Tubulitis. American Journal of Transplantation 2009, 9:1347-1353.
49. Hauser IA, Spiegler S, Kiss E, Gauer S, Sichler O, Scheuermann EH, Ackermann H, Pfeilschifter JM, Geiger H, Grone HJ, Radeke HH: Prediction of acute renal allograft rejection by urinary monokine induced by IFNgamma (MIG). Journal of the American Society of Nephrology 2005, 16:1849-1858

50. Hu HZ, Aizenstein BD, Puchalski A, Burmania JA, Hamawy MM, Knechtle SJ: Elevation of CXCR3-binding chemokines in urine indicates acute renalallograft dysfunction. American Journal of Transplantation 2004, 4:432-437.

51. Tatapudi RR, Muthukumar T, Dadhania D, Ding R, Li BG, Sharma VK, LozadaPastorio E, Seetharamu N, Hartono C, Serur D, et al: Noninvasive detection of renal allograft inflammation by measurements of mRNA for IP-10 and CXCR3 in urine. Kidney International 2004, 65:2390-2397.

52. Hidalgo LG, Urmson J, Ramassar V, Halloran PF: IFN-gamma directly modulates lymphocyte cytotoxicity. Faseb Journal 2002, 16:A1086-A1086.

53. Hidalgo LG, Urmson J, Halloran PF: IFN-gamma decreases CTL generation by limiting IL-2 production: A feedback loop controlling effector cell production. American Journal of Transplantation 2005, 5:651-661.

54. Hidalgo LG, Halloran PF: Role of IFN-gamma in allograft rejection. Critical Reviews in Immunology 2002, 22:317-349.

55. Schoenborn JR, Wilson CB: Regulation of interferon-gamma during innate and adaptive immune responses. Advances in Immunology 2007 96:41-101.

56. Kirk AD, Bollinger RR, Finn OJ: Rapid, Comprehensive Analysis of Human Cytokine Messenger-Rna and Its Application to the Study of Acute Renal-Allograft Rejection. Human Immunology 1995, 43:113-128.

57. Moudgil A, Bagga A, Toyoda M, Nicolaidou E, Jordan SC, Ross D: Expression of gamma-IFN mRNA in bronchoalveolar lavage fluid correlates with early acute allograft rejection in lung transplant recipients. Clinical Transplantation 1999, 13:201-207.

58. Nast CC, Zuo XJ, Prehn J, Danovitch GM, Wilkinson A, Jordan SC: GammaInterferon Gene-Expression in Human Renal-Allograft Fine-Needle Aspirates. Transplantation 1994, 57:498-502.

59. Lande JD, Gimino VJ, Hertz MI, King RA: Characterization of lung allograft rejection using microarray gene expression profiling. American Journal of Human Genetics 2002, 71:392-392.

60. Pos Z, Selleri S, Spivey TL, Wang JK, Liu H, Worschech A, Sabatino M, Monaco A, Leitman SF, Falus A, et al: Genomic scale analysis of racial impact on response to IFN-alpha. Proceedings of the National Academy of Sciences of the United States of America 2010, 107:803-808.

61. de Veer MJ, Holko M, Frevel M, Walker E, Der S, Paranjape JM, Silverman RH, Williams BRG: Functional classification of interferon-stimulated genes identified using microarrays. Journal of Leukocyte Biology 2001, 69:912-920.

62. Reeve J, Einecke G, Kaplan B, Halloran PF: A microarray-based classifier for diagnosing rejection in kidney transplants: The top diagnostic genes for rejection are interferon-gamma induced. American Journal of Transplantation 2008, 8:246-246.

63. Ramassar V, Urmson J, Hobart M, Goes N, Halloran PF: Class II transactivator (CIITA) mediates the in vivo induction of class II in mouse tissues. Faseb Journal 1996, 10:2262-2262.

64. Goes N, Hobart M, Ramassar V, Halloran PF: Role of IFN-gamma and IRF-1 in injury-induced and basal MHC class I and II expression. Faseb Journal 1996, 10:2184-2184

65. Zhu JF, Paul WE: CD4 T cells: fates, functions, and faults. Blood 2008, 112:1557-1569.

66. Ramsey SA, Klemm SL, Zak DE, Kennedy KA, Thorsson V, Li B, Gilchrist M, Gold ES, Johnson CD, Litvak $V$, et al: Uncovering a macrophage transcriptional program by integrating evidence from motif scanning and expression dynamics. Plos Computational Biology 2008, 4.

67. Yeruva S, Ramadori G, Raddatz D: NF-kappa B-dependent synergistic regulation of CXCL10 gene expression by IL-1 beta and IFN-gamma in human intestinal epithelial cell lines. International Journal of Colorectal Disease 2008, 23:305-317.

68. Liu JG, Guan $X Q$, Ma XJ: Interferon regulatory factor 1 is an essential and direct transcriptional activator for interferon gamma-induced RANTES/ CC15 expression in macrophages. Journal of Biological Chemistry 2005, 280:24347-24355

69. Zhao DXM, Hu YY, Miller GG, Luster AD, Mitchell RN, Libby P: Differential expression of the IFN-gamma-inducible CXCR3-binding chemokines, IFNinducible protein 10, monokine induced by IFN, and IFN-inducible T cell alpha chemoattractant in human cardiac allografts: Association with 
cardiac allograft vasculopathy and acute rejection. Journal of Immunology 2002, 169:1556-1560

70. Fahmy NM, Yamani MH, Starling RC, Ratliff NB, Young JB, McCarthy PM, Feng JY, Novick AC, Fairchild RL: Chemokine and chemokine receptor gene expression indicates acute rejection of human cardiac transplants. Transplantation 2003, 75:72-78.

71. Belperio JA, Keane MP, Burdick MD, Lynch JP, Zisman DA, Xue YY, Li KW Ardehali A, Ross DJ, Strieter RM: Role of CXCL9/CXCR3 chemokine biology during pathogenesis of acute lung allograft rejection. Journal of Immunology 2003, 171:4844-4852.

72. Melter M, Exeni A, Reinders MEJ, Fang JC, McMahon G, Ganz P, Hancock WW, Briscoe DM: Expression of the chemokine receptor CXCR3 and its ligand IP-10 during human cardiac allograft rejection. Circulation 2001, 104:2558-2564

73. Fischereder M, Luckow B, Hocher B, Wuthrich RP, Rothenpieler U, Schneeberger H, Panzer U, Stahl RAK, Hauser IA, Budde K, et al: CC chemokine receptor 5 and renal-transplant survival. Lancet 2001, 357:1758-1761

74. Heidenhain C, Pulhl G, Moench C, Lautem A, Neuhaus P: Chemokine receptor 5 Delta 32 mutation reduces the risk of acute rejection in liver transplantation. Annals of Transplantation 2009, 14:36-44.

75. Hancock WW, Lu B, Gao W, Csizmadia V, Faia K, King JA, Smiley ST, Ling M, Gerard NP, Gerard C: Requirement of the chemokine receptor CXCR3 for acute allograft rejection. Journal of Experimental Medicine 2000, 192:1515-1519.

76. Hancock WW, Gao W, Csizmadia V, Faia KL, Shemmeri N, Luster AD: Donorderived IP-10 initiates development of acute allograft rejection. Journal of Experimental Medicine 2001, 193:975-980.

77. Hancock WW, Wang LQ, Ye QR, Han RX, Lee I: Chemokines and their receptors as markers of allograft rejection and targets for immunosuppression. Current Opinion in Immunology 2003, 15:479-486.

78. Gao W, Faia KL, Csizmadia V, Smiley ST, Soler D, King JA, Danoff TM, Hancock WW: Beneficial effects of targeting CCR5 in allograft recipients. Transplantation 2001, 72:1199-1205.

79. Gao P, Zhou XY, Yashiro-Ohtani Y, Yang YF, Sugimoto N, Ono S, Nakanishi T, Obika S, Imanishi T, Egawa T, et al: The unique target specificity of a nonpeptide chemokine receptor antagonist: selective blockade of two Th1 chemokine receptors CCR5 and CXCR3. Journal of Leukocyte Biology 2003, 73:273-280.

80. Halloran PF, Fairchild RL: The puzzling role of CXCR3 and its ligands in organ allograft rejection. American Journal of Transplantation 2008, 8:1578-1579

81. Haskova Z, Izawa A, Contreras AG, Flynn E, Boulday G, Briscoe DM: Organspecific differences in the function of MCP-1 and CXCR3 during cardiac and skin allograft rejection. Transplantation 2007, 83:1595-1601.

82. Kwun J, Hazinedaroglu SM, Schadde E, Kayaoglu HA, Fechner J, Hu HZ, Roenneburg D, Torrealba J, Shiao L, Hong X, et al: Unaltered graft survival and intragraft lymphocytes infiltration in the cardiac allograft of Cxcr3 (-/-) mouse recipients. American Journal of Transplantation 2008, 8:1593-1603.

83. Zerwes HG, Li J, Kovarik J, Streiff M, Hofmann M, Roth L, Luyten M, Pally C, Loewe RP, Wieczorek G, et al: The chemokine receptor Cxcr3 is not essential for acute cardiac allograft rejection in mice and rats. American Journal of Transplantation 2008, 8:1604-1613.

84. Morris MA, Ley K: Trafficking of natural killer cells. Curr Mol Med 2004, 4:431-438.

85. Murphy PM, Baggiolini M, Charo IF, Hebert CA, Horuk R, Matsushima K, Miller LH, Oppenheim JJ, Power CA: International union of pharmacology. XXII. Nomenclature for chemokine receptors. Pharmacological Reviews 2000, 52:145-176.

86. Moser B, Wolf M, Walz A, Loetscher P: Chemokines: multiple levels of leukocyte migration control. Trends in Immunology 2004, 25:75-84.

87. Deola S, Panelli MC, Maric D, Selleri S, Dmitrieva NI, Voss CY, Klein H, Stroncek D, Wang E, Marincola FM: Helper B cells promote cytotoxic T cell survival and proliferation independently of antigen presentation through CD27/CD70 interactions. Journal of Immunology 2008, 180:1362-1372

88. Hoffmann U, Sergerer S, Rummele P, Kruger B, Pietrzyk M, Hofstadter F, Banas B, Kramer BK: Expression of the chemokine receptor CXCR3 in human renal allografts-a prospective study. Nephrology Dialysis Transplantation 2006, 21:1373-1381.
89. Xanthou G, Duchesnes CE, Williams TJ, Pease JE: CCR3 functional responses are regulated by both CXCR3 and its ligands CXCL9, CXCL10 and CXCL11. Eur J Immunol 2003, 33:2241-2250.

90. Halloran PF: T cell-mediated rejection of kidney transplants: a personal viewpoint. Am J Transplant 2010, 10:1126-1134.

91. Qin SX, Rottman JB, Myers P, Kassam N, Weinblatt M, Loetscher M, Koch AE, Moser B, Mackay CR: The chemokine receptors CXCR3 and CCR5 mark subsets of T cells associated with certain inflammatory reactions. Journal of Clinical Investigation 1998, 101:746-754.

92. Jones D, Benjamin RJ, Shahsafaei A, Dorfman DM: The chemokine receptor CXCR3 is expressed in a subset of B-cell lymphomas and is a marker of B-cell chronic lymphocytic leukemia. Blood 2000, 95:627-632.

93. Drayton DL, Liao S, Mounzer RH, Ruddle NH: Lymphoid organ development: from ontogeny to neogenesis. Nat Immunol 2006 7:344-353.

94. Krensky AM, Clayberger C: Biology and clinical relevance of granulysin. Tissue Antigens 2009, 73:193-198.

95. Obara H, Nagasaki K, Hsieh CL, Ogura Y, Esquivel CO, Martinez OM, Krams SM: IFN-gamma, produced by NK cells that infiltrate liver allografts early after transplantation, links the innate and adaptive immune responses. Am J Transplant 2005, 5:2094-2103.

96. Kondo T, Morita K, Watarai Y, Auerbach MB, Taub DD, Novick AC, Toma H, Fairchild RL: Early increased chemokine expression and production in murine allogeneic skin grafts is mediated by natural killer cells. Transplantation 2000, 69:969-977.

97. Larosa DF, Rahman AH, Turka LA: The innate immune system in allograft rejection and tolerance. Journal of Immunology 2007, 178:7503-7509.

98. Kitchens WH, Uehara S, Chase CM, Colvin RB, Russell PS, Madsen JC: The changing role of natural killer cells in solid organ rejection and tolerance. Transplantation 2006, 81:811-817.

99. Bingaman AW, Ha J, Waitze SY, Durham MM, Cho HR, Tucker-Burden C, Hendrix R, Cowan SR, Pearson TC, Larsen CP: Vigorous allograft rejection in the absence of danger. Journal of Immunology 2000, 164:3065-3071.

100. Worschech A, Chen NH, Yu YA, Zhang Q, Pos Z, Weibel S, Raab V, Sabatino M, Monaco A, Liu H, et al: Systemic treatment of xenografts with vaccinia virus GLV-1h68 reveals the immunologic facet of oncolytic therapy. Bmc Genomics 2009, 10.

101. Andersen CB, Ladefoged SD, Larsen S: Acute Kidney Graft-Rejection - A Morphological and Immunohistological Study on Zero-Hour and FollowUp Biopsies with Special Emphasis on Cellular Infiltrates and Adhesion Molecules. Apmis 1994, 102:23-37.

102. Meehan SM, McCluskey RT, Pascual M, Preffer Fl, Anderson P, Schlossman SF, Colvin RB: Cytotoxicity and apoptosis in human renal allografts: Identification, distribution, and quantitation of cells with a cytotoxic granule protein GMP-17 (TIA-1) and cells with fragmented nuclear DNA. Laboratory Investigation 1997, 76:639-649.

103. Sagoo P, Perucha E, Sawitzki B, Tomiuk S, Stephens DA, Miqueu P, Chapman S, Craciun L, Sergeant R, Brouard S, et al: Development of a cross-platform biomarker signature to detect renal transplant tolerance in humans. J Clin Invest 2010, 120:1848-1861.

104. Cassese G, Lindenau S, de Boer B, Arce S, Hauser A, Riemekasten G, Berek C, Hiepe F, Krenn V, Radbruch A, Manz RA: Inflamed kidneys of NZB/W mice are a major site for the homeostasis of plasma cells. European Journal of Immunology 2001, 31:2726-2732.

105. Magalhaes R, Stiehl P, Morawietz L, Berek C, Krenn V: Morphological and molecular pathology of the $B$ cell response in synovitis of rheumatoid arthritis. Virchows Archiv 2002, 441:415-427.

106. Platt JL, Lebien TW, Michael AF: Interstitial Mononuclear Cell-Populations in Renal Graft-Rejection - Identification by Monoclonal-Antibodies in Tissue-Sections. Journal of Experimental Medicine 1982, 155:17-30.

107. Zarkhin V, Sarwal MM: Microarrays: Monitoring for Transplant Tolerance and Mechanistic Insights. Clinics in Laboratory Medicine 2008, 28:385-+.

108. Racusen LC, Colvin RB, Solez K, Mihatsch MJ, Halloran PF, Campbell PM, Cecka MJ, Cosyns JP, Demetris AJ, Fishbein MC, et al: Antibody-mediated rejection criteria - an addition to the Banff ' 97 Classification of Renal Allograft Rejection. American Journal of Transplantation 2003, 3:708-714.

109. Alausa M, Almagro U, Siddiqi N, Zuiderweg R, Medipalli R, Hariharan S: Refractory acute kidney transplant rejection with CD20 graft infiltrates and successful therapy with rituximab. Clinical Transplantation 2005, 19:137-140. 
110. Bagnasco SM, Tsai W, Rahman MH, Kraus ES, Barisoni L, Vega R, Racusen LC, Haas M, Mohammed BS, Zachary AA, Montgomery RA: CD20-positive infiltrates in renal allograft biopsies with acute cellular rejection are not associated with worse graft survival. American Journal of Transplantation 2007, 7:1968-1973.

111. Doria C, di Francesco F, Ramirez CB, Frank A, laria M, Francos G, Marino IR, Farber $J$ : The presence of B-cell nodules does not necessarily portend a less favorable outcome to therapy in patients with acute cellular rejection of a renal allograft. Transplantation Proceedings 2006, 38:3441-3444

112. Hippen BE, DeMattos A, Cook WJ, Kew CE, Gaston RS: Association of CD20 +infiltrates with poorer clinical outcomes in acute cellular rejection of renal allografts. American Journal of Transplantation 2005, 5:2248-2252.

113. Kayler LK, Lakkis FG, Morgan C, Basu A, Blisard D, Tan HP, Shapiro R, Randhawa PS: Acute cellular rejection with CD20-Positive lymphoid clusters in kidney transplant patients following lymphocyte depletion. American Journal of Transplantation 2007, 7:357-357.

114. Krukemeyer MG, Moeller J, Morawietz L, Rudolph B, Neumann U, Theruvath T, Neuhaus P, Krenn V: Description of B lymphocytes and plasma cells, complement, and chemokines/receptors in acute liver allograft rejection. Transplantation 2004, 78:65-70.

115. Tsai EW, Rianthavorn P, Gjertson DW, Wallace WD, Reed EF, Ettenger RB: CD20+lymphocytes in renal allografts are associated with poor graft survival in pediatric patients. Transplantation 2006, 82:1769-1773.

116. Mengel M, Bogers J, Bosmans JL, Seron D, Moreso F, Carrera M, Gwinner W, Schwarz A, De Broe M, Kreipe H, Haller H: Incidence of C4d stain in protocol biopsies from renal allografts: Results from a multicenter trial. American Journal of Transplantation 2005, 5:1050-1056.

117. Martins HL, Silva C, Martini D, Noronha IL: Detection of B lymphocytes $(C D 20(+))$ in renal allograft biopsy specimens. Transplantation Proceedings 2007, 39:432-434.

118. Zarkhin V, Kambham N, Li L, Kwok S, Hsieh SC, Salvatierra O, Sarwal MM Characterization of intra-graft $B$ cells during renal allograft rejection. Kidney International 2008, 74:664-673.

119. Noorchashm H, Reed AJ, Rostami SY, Mozaffari R, Zekavat G, Koeberlein B, Caton AJ, Naji A: B cell-mediated antigen presentation is required for the pathogenesis of acute cardiac allograft rejection. Journal of Immunology 2006, 177:7715-7722

120. Schultz KR, Klarnet JP, Gieni RS, Hayglass KT, Greenberg PD: The Role of BCells for Invivo T-Cell Responses to A Friend Virus-Induced Leukemia. Science 1990, 249:921-923.

121. Yang X, Brunham RC: Gene knockout B cell-deficient mice demonstrate that $B$ cells play an important role in the initiation of $T$ cell responses to Chlamydia trachomatis (mouse pneumonitis) lung infection. Journal of Immunology 1998, 161:1439-1446.

122. Cross AH, Stark JL, Lauber J, Ramsbottom MJ, Lyons JA: Rituximab reduces $B$ cells and T cells in cerebrospinal fluid of multiple sclerosis patients. Journal of Neuroimmunology 2006, 180:63-70

123. Ascierto $M$, Kmieciak $M$, Idowu $M$, Manjili $R$, Zhao $Y$, Nikizad H, Grimes $M$, Dumur $C$, Wang $E$, Wang $X$, et al: A signature of immune function genes associated with recurrence-free survival in breast cancer patients. Breast Cancer Resarch and Treatment 2011.

124. Zarkhin V, Chalasani G, Sarwal MM: The yin and yang of B cells in graft rejection and tolerance. Transplant Rev (Orlando) 2010, 24:67-78.

125. Tyden G, Genberg H, Tollemar J, Ekberg H, Persson NH, Tufveson G, Wadstrom J, Gabel M, Mjornstedt L: A randomized, doubleblind, placebocontrolled, study of single-dose rituximab as induction in renal transplantation. Transplantation 2009, 87:1325-1329.

126. Clatworthy MR, Watson CJ, Plotnek G, Bardsley V, Chaudhry AN, Bradley JA, Smith KG: B-cell-depleting induction therapy and acute cellular rejection. N Engl J Med 2009, 360:2683-2685.

127. Bedognetti D, Zoppoli G, Massucco C, Zanardi E, Zupo S, Bruzzone A, Sertoli MR, Balleari $E$, Racchi $O$, Messina M, et al: Impaired response to influenza vaccine associated with persistent memory $B$ cell depletion in non-Hodgkin's lymphoma patients treated with rituximab-containing regimens. J Immunol 2011, 186:6044-55

128. Newell KA, Asare A, Kirk AD, Gisler TD, Bourcier K, Suthanthiran M, Burlingham WJ, Marks WH, Sanz I, Lechler Rl, et al: Identification of a B cell signature associated with renal transplant tolerance in humans. J Clin Invest 2010, 120:1836-1847.
129. Louis S, Braudeau C, Giral M, Dupont A, Moizant F, Robillard N, Moreau A, Soulillou JP, Brouard S: Contrasting CD25hiCD4+T cells/FOXP3 patterns in chronic rejection and operational drug-free tolerance. Transplantation 2006, 81:398-407.

130. Pallier A, Hillion S, Danger R, Giral M, Racape M, Degauque N, Dugast E, Ashton-Chess J, Pettre S, Lozano JJ, et al: Patients with drug-free longterm graft function display increased numbers of peripheral B cells with a memory and inhibitory phenotype. Kidney Int 2010, 78:503-513.

131. Sharma R, Jarjour WN, Zheng L, Gaskin F, Fu SM, Ju ST: Large functional repertoire of regulatory T-cell suppressible autoimmune T cells in scurfy mice. J Autoimmun 2007, 29:10-19.

132. Wildin RS, Freitas A: IPEX and FOXP3: clinical and research perspectives. J Autoimmun 2005, , 25 Suppl: 56-62.

133. Lee WS, Park S, Lee WY, Yun SH, Chun HK: Clinical impact of tumorinfiltrating lymphocytes for survival in stage II colon cancer. Cancer 2010, 116:5188-5199.

134. Correale P, Rotundo MS, Del Vecchio MT, Remondo C, Migali C, Ginanneschi C, Tsang KY, Licchetta A, Mannucci S, Loiacono L, et al: Regulatory (FoxP3+) T-cell tumor infiltration is a favorable prognostic factor in advanced colon cancer patients undergoing chemo or chemoimmunotherapy. J Immunother 2010, 33:435-441.

135. Muthukumar T, Dadhania D, Ding R, Snopkowski C, Naqvi R, Lee JB, Hartono C, Li B, Sharma VK, Seshan SV, et al: Messenger RNA for FOXP3 in the urine of renal-allograft recipients. N Engl J Med 2005, 353:2342-2351.

136. Bunnag S, Allanach K, Jhangri GS, Sis B, Einecke G, Mengel M, Mueller TF, Halloran PF: FOXP3 expression in human kidney transplant biopsies is associated with rejection and time post transplant but not with favorable outcomes. American Journal of Transplantation 2008, 8:1423-1433.

137. Matzinger P: The danger model: A renewed sense of self. Science 2002, 296:301-305.

138. Vabulas RM, Ahmad-Nejad P, Ghose S, Kirschning CJ, Issels RD, Wagner H: HSP70 as endogenous stimulus of the toll/interleukin-1 receptor signal pathway. Journal of Biological Chemistry 2002, 277:15107-15112.

139. Platanias LC: Mechanisms of type-I- and type-II-interferon-mediated signalling. Nature Reviews Immunology 2005, 5:375-386

140. Reich NC, Liu L: Tracking STAT nuclear traffic. Nature Reviews Immunology 2006, 6:602-612.

141. Muller-Ladner U, Alten R, Heiligenhaus A, Kekow J, Koletzko S, Mrowietz U, Ochsenkuhn T, Radke M, Reich K, Rudwaleit M, Schreiber S: "TRECID", TNF alpha related chronic inflammatory diseases - A new multiple diseases bridging concept. Deutsche Medizinische Wochenschrift 2009, 134:2132-2136

142. Connolly MK, Bedrosian AS, Clair JMS, Mitchell AP, Ibrahim J, Stroud A, Pachter HL, Bar-Sagi D, Frey AB, Miller G: In liver fibrosis, dendritic cells govern hepatic inflammation in mice via TNF-alpha. Journal of Clinical Investigation 2009, 119:3213-3225.

143. Le Moine A, Goldman M, Abramowicz D: Multiple pathways to allograft rejection. Transplantation 2002, 73:1373-1381.

144. Bonizzi G, Karin M: The two NF-kappa B activation pathways and their role in innate and adaptive immunity. Trends in Immunology 2004, 25:280-288.

145. Akira S, Uematsu S, Takeuchi O: Pathogen recognition and innate immunity. Cell 2006, 124:783-801

146. Iwasaki A, Medzhitov R: Toll-like receptor control of the adaptive immune responses. Nature Immunology 2004, 5:987-995.

147. Brent $\mathrm{L}$ : The 50th anniversary of the discovery of immunologic tolerance. New England Journal of Medicine 2003, 349:1381-1383.

148. Brouard S, Mansfield E, Braud C, Li L, Giral M, Hsieh SC, Baeten D, Zhang M, Ashton-Chess J, Braudeau C, et al: Identification of a peripheral blood transcriptional biomarker panel associated with operational renal allograft tolerance. Proceedings of the National Academy of Sciences of the United States of America 2007, 104:15448-15453.

149. Lin T, Zhou WD, Sacks SH: The role of complement and Toll-like receptors in organ transplantation. Transplant International 2007, 20:481-489.

150. Sacks $S$, Lee $Q$, Wong $W$, Zhou W: The role of complement in regulating the alloresponse. Current Opinion in Organ Transplantation 2009, 14:10-15.

151. Sacks SH, Chowdhury P, Zhou WD: Role of the complement system in rejection. Current Opinion in Immunology 2003, 15:487-492.

152. Lee Jl, Burckart GJ: Nuclear factor kappa B: Important transcription factor and therapeutic target. Journal of Clinical Pharmacology 1998, 38:981-993. 
153. Schreiber J, Jenner RG, Murray HL, Gerber GK, Gifford DK, Young RA: Coordinated binding of NF-kappa B family members in the response of human cells to lipopolysaccharide. Proceedings of the National Academy of Sciences of the United States of America 2006, 103:5899-5904.

154. Peng Q, Li K, Patel H, Sacks SH, Zhou WD: Dendritic cell synthesis of C3 is required for full $\mathrm{T}$ cell activation and development of a Th1 phenotype. Journal of Immunology 2006, 176:3330-3341.

155. Kawamoto S, Yalcindag A, Laouini D, Brodeur S, Bryce P, Lu B, Humbles AA, Oettgen H, Gerard C, Geha RS: The anaphylatoxin C3a downregulates the Th2 response to epicutaneously introduced antigen. Journal of Clinical Investigation 2004, 114:399-407.

156. Carroll MC: The complement system in B cell regulation. Molecular Immunology 2004, 41:141-146.

157. Pratt JR, Basheer SA, Sacks SH: Local synthesis of complement component C3 regulates acute renal transplant rejection. Nature Medicine 2002, 8:582-587.

158. Li K, Patel H, Farrar CA, Hargreaves REG, Sacks SH, Zhou WD: Complement activation regulates the capacity of proximal tubular epithelial cell to stimulate alloreactive T cell response. Journal of the American Society of Nephrology 2004, 15:2414-2422.

159. Cordoba SP, Wang CM, Williams R, Li J, Smit L, Sharland A, Allen R, McCaughan G, Bishop A: Gene array analysis of a rat model of liver transplant tolerance identifies increased complement C3 and the STAT1/IRF-1 pathway during tolerance induction. Liver Transplantation 2006, 12:636-643.

160. Fujino M, Kitazawa Y, Kawasaki M, Funeshima N, Kimura H, Nakajima T, Saito H, Li XK: Differences in lymphocyte gene expression between tolerant and syngeneic liver grafted rats. Liver Transplantation 2004, 10:379-391.

161. Pan TL, Wang PW, Huang CC, Goto S, Chen CL: Expression, by functional proteomics, of spontaneous tolerance in rat orthotopic liver transplantation. Immunology 2004, 113:57-64.

162. Naesens M, Li L, Ying LH, Sansanwal P, Sigdel TK, Hsieh SC, Kambham N Lerut E, Salvatierra O, Butte AJ, Sarwal MM: Expression of Complement Components Differs Between Kidney Allografts from Living and Deceased Donors. Journal of the American Society of Nephrology 2009, 20:1839-1851.

163. Moore KW, Malefyt RD, Coffman RL, O'Garra A: Interleukin-10 and the interleukin-10 receptor. Annual Review of Immunology 2001, 19:683-765.

164. Mocellin S, Panelli MC, Wang E, Nagorsen D, Marincola FM: The dual role of IL-10. Trends in Immunology 2003, 24:36-43.

165. Mocellin S, Panelli M, Wang E, Rossi CR, Pilati P, Nitti D, Lise M, Marincola FM: IL-10 stimulatory effects on human NK cells explored by gene profile analysis. Genes and Immunity 2004, 5:621-630.

166. Mocellin S, Marincola FM, Young HA: Interleukin-10 and the immune response against cancer: a counterpoint. Journal of Leukocyte Biology 2005, 78:1043-1051.

167. Tao M, Li BR, Nayini J, Sivaraman S, Song SW, Larson A, Toofanfard M, Chen H, Venugopal P, Preisler HD: In vivo effects of IL-4, IL-10, and amifostine on cytokine production in patients with acute myelogenous leukemia. Leukemia \& Lymphoma 2001, 41:161-168.

168. Lauw FN, Pajkrt D, Hack CE, Kurimoto M, van Deventer SJH, van der Poll T: Proinflammatory effects of IL-10 during human endotoxemia. Journal of Immunology 2000, 165:2783-2789.

169. Del Vecchio M, Mortarini R, Canova S, Di Guardo L, Pimpinelli N, Sertoli MR, Bedognetti D, Queirolo P, Morosini P, Perrone T, et al: Bevacizumab plus fotemustine as first-line treatment in metastatic melanoma patients: clinical activity and modulation of angiogenesis and lymphangiogenesis factors. Clin Cancer Res 2010, 16:5862-5872.

170. Qian SG, Li W, Li YP, Fu FM, Lu LN, Fung JJ, Thomson AW: Systemic administration of cellular interleukin-10 can exacerbate cardiac allograft rejection in mice. Transplantation 1996, 62:1709-1714.

171. Li W, Lu L, Li Y, Fu F, Fung JJ, Thomson AW, Qian S: High-dose cellular IL10 exacerbates rejection and reverses effects of cyclosporine and tacrolimus in mouse cardiac transplantation. Transplantation Proceedings 1997, 29:1081-1082.

172. Li W, Fu F, Lu L, Narula SK, Fung JJ, Thomson AW, Qian S: Systemic administration of anti-interleukin-10 antibody prolongs organ allograft survival in normal and presensitized recipients. Transplantation 1998, 66:1587-1596.
173. Karczewski J, Karczewski M, Wiktorowicz K, Glyda M: Cytometric Analysis of Th1/Th2 Cytokines in the Urine of Patients Prior to the Kideny Transplantation. Transplant International 2009, 22:145-145.

174. Grinyo J, Vanrenterghem Y, Nashan B, Vincenti F, Ekberg H, Lindpaintner K, Rashford M, Nasmyth-Miller C, Voulgari A, Spleiss O, et al: Association of four DNA polymorphisms with acute rejection after kidney transplantation. Transplant International 2008, 21:879-891.

175. Honda K, Taniguchi T: IRFs: master regulators of signalling by Toll-like receptors and cytosolic pattern-recognition receptors. Nature Reviews Immunology 2006, 6:644-658.

176. Vila-del Sol V, Punzon C, Fresno M: IFN-gamma-induced TNF-alpha expression is regulated by interferon regulatory factors 1 and 8 in mouse macrophages. Journal of Immunology 2008, 181:4461-4470.

177. Penninger JM, Sirard C, Mittrucker HW, Chidgey A, Kozieradzki I, Nghiem M, Hakem A, Kimura T, Timms E, Boyd R, et al: The interferon regulatory transcription factor IRF-1 controls positive and negative selection of CD8 (+) thymocytes. Immunity 1997, 7:243-254.

178. Taki S, Sato T, Ogasawara K, Fukuda T, Sato M, Hida S, Suzuki G, Mitsuyama M, Shin EH, Kojima S, et al: Multistage regulation of Th1-type immune responses by the transcription factor IRF-1. Immunity 1997, 6:673-679.

179. Ogasawara K, Hida S, Azimi N, Tagaya Y, Sato T, Yokochi-Fukuda T, Waldmann TA, Taniguchi T, Taki S: Requirement for IRF-1 in the microenvironment supporting development of natural killer cells (vol 391, pg 700, 1998). Nature 1998, 392:843-843.

180. Hama N, Yanagisawa Y, Dono K, Kobayashi S, Marubashi S, Nagano H, Umeshita K, Watanabe S, Uchiyama Y, Monden M: Gene Expression Profiling of Acute Cellular Rejection in Rat Liver Transplantation Using DNA Microarrays. Liver Transplantation 2009, 15:509-521.

181. Stegall M, Park W, Kim D, Kremers W: Gene expression during acute allograft rejection: Novel statistical analysis of microarray data. American Journal of Transplantation 2002, 2:913-925.

182. Erickson LM, Pan F, Ebbs A, Kobayashi M, Jiang HS: Microarray-based gene expression profiles of allograft rejection and immunosuppression in the rat heart transplantation model. Transplantation 2003, 76:582-588.

183. Kroger A, Koster M, Schroeder K, Hauser H, Mueller PP: Activities of IRF-1. Journal of Interferon and Cytokine Research 2002, 22:5-14.

184. Jin P, Wang E, Provenzano M, Stroncekl D, Marincoial FM: Gene expression signatures of interleukin-2 in vivo and in vitro and their relation to anticancer therapy. Critical Reviews in Immunology 2007, 27:437-448.

185. Matsuyama T, Kimura T, Kitagawa M, Pfeffer K, Kawakami T, Watanabe N, Kundig TM, Amakawa R, Kishihara K, Wakeham A, et al: Targeted Disruption of Irf-1 Or Irf-2 Results in Abnormal Type-I Ifn Gene Induction and Aberrant Lymphocyte Development. Cell 1993, 75:83-97.

186. Erickson L, Crews G, Pan F, Fisniku O, Jang MS, Wynn C, Kobayashi M, Jiang HS: Unique gene expression profiles of heart allograft rejection in the interferon regulatory factor-1-deficient mouse. Transplant Immunology 2004, 13:169-175.

187. Mansfield ES, Sarwal MM: Arraying the orchestration of allograft pathology. American Journal of Transplantation 2004, 4:853-862.

188. Bonadies N, Neururer C, Steege A, Vallabhapurapu S, Pabst T, Mueller BU: PU.1 is regulated by NF-kappaB through a novel binding site in a $17 \mathrm{~kb}$ upstream enhancer element. Oncogene 2010, 29:1062-1072.

189. Finn PW, Stone JR, Boothby MR, Perkins DL: Inhibition of NF-kappa Bdependent $T$ cell activation abrogates acute allograft rejection. Journal of Immunology 2001, 167:5994-6001.

190. Basil CF, Zhao YD, Zavaglia K, Jin P, Panelli MC, Voiculescu S, Mandruzzato S, Lee HM, Seliger B, Freedman RS, et al: Common cancer biomarkers. Cancer Research 2006, 66:2953-2961.

191. Tiao MM, Lu L, Tao R, Wang L, Fung JJ, Qian SG: Prolongation of cardiac allograft survival by systemic administration of immature recipient dendritic cells deficient in NF-kappa B activity. Annals of Surgery 2005, 241:497-505.

192. Ohmori K, Takeda S, Miyoshi S, Minami M, Nakane S, Ohta M, Sawa Y, Matsuda $\mathrm{H}$ : Attenuation of lung injury in allograft rejection using NFkappa B decoy transfection - novel strategy for use in lung transplantation. European Journal of Cardio-Thoracic Surgery 2005, 27:23-27.

193. Zhou P, Hwang KW, Palucki DA, Guo Z, Boothby M, Newell KA, Alegre ML: Impaired NF-kappa B activation in T cells permits tolerance to primary heart allografts and to secondary donor skin grafts. American Journal of Transplantation 2003, 3:139-147. 
194. Marincola FM, Wang E: Immunologic signatures of rejection. New York, NY: Springer; 2010

195. Pos Z, Galon J: Predictors of favorable outcome in cancer. In Immunologic signatures of rejection. Edited by: Marincola FM, Wang E. New York: Springer; 2010:199-210

196. Bedognetti D: Signatures Associated with Acute Rejection: Allograft Rejection. In: Immunologic signatures of rejection.Edited by: Marincola FM, Wang E. New York: Springer; 2010:305-345

197. Ascierto ML, De Giorgi V, Liu Q, Bedognetti D, Spivey T, Murtas D, Uccellini L, Ayotte BD, Stroncek DF, Chouchane L, et al: An immunologic portrait of cancer. J Transl Med 2011.

198. Castiello L, Sabatino M, Jin P, Clayberger C, Marincola FM, Krensky AM, Stroncek DF: Monocyte-derived DC maturation strategies and related pathways: a transcriptional view. Cancer Immunol Immunother 2011, 60:457-466.

doi:10.1186/1479-5876-9-174

Cite this article as: Spivey et al:: Gene expression profiling in acute allograft rejection: challenging the immunologic constant of rejection hypothesis. Journal of Translational Medicine 2011 9:174.

\section{Submit your next manuscript to BioMed Central} and take full advantage of:

- Convenient online submission

- Thorough peer review

- No space constraints or color figure charges

- Immediate publication on acceptance

- Inclusion in PubMed, CAS, Scopus and Google Scholar

- Research which is freely available for redistribution

Submit your manuscript at www.biomedcentral.com/submit 